\title{
Diversity, distribution and spatial structure of the cold-water coral fauna of the Azores (NE Atlantic)
}

\author{
A. Braga-Henriques ${ }^{1}$, F. M. Porteiro ${ }^{1}$, P. A. Ribeiro ${ }^{1}$, V. de Matos $^{1}$, Í. Sampaio ${ }^{1}$, O. Ocaña ${ }^{2}$, and R. S. Santos ${ }^{1}$ \\ ${ }^{1}$ Centre of IMAR of the University of the Azores, Department of Oceanography and Fisheries (DOP) and LARSyS \\ Associated Laboratory, Rua Prof. Dr. Frederico Machado 4, 9901-862 Horta, Portugal \\ ${ }^{2}$ Fundación Museo del Mar, Autoridad Portuaria de Ceuta, Muelle Cañonero, 51001 Ceuta (North Africa), Spain
}

Correspondence to: A. Braga-Henriques (andreiahenriques@uac.pt)

Received: 29 November 2012 - Published in Biogeosciences Discuss.: 9 January 2013

Revised: 9 April 2013 - Accepted: 8 May 2013 - Published: 19 June 2013

\begin{abstract}
Cold-water corals are widely considered as important structural components of benthic habitats, potentially enhancing local abundance in a variety of fish and invertebrate species. Yet, current knowledge of the taxonomic diversity and distribution patterns of these vulnerable, slow-growing organisms is scarce and fragmented, limiting the effectiveness of spatial management and conservation measures. We have conducted an exhaustive compilation of records of alcyonaceans, antipatharians, scleractinians and stylasterids available through present day to assess the diversity, distribution and spatial structure of coral assemblages in the Azores exclusive economic zone (EEZ). The resulting database comprises 2501 entries concerning historical oceanographic expeditions and other published sources, as well as unpublished data from bottom longline by-catch. Our taxonomic inventory appears to be fairly complete for the explored habitats, accounting for 164 species (79 alcyonaceans, 58 scleractinians, 18 antipatharians and 9 stylasterids), nine of which were documented for the first time. The Azores EEZ harbours a mixed coral fauna with several zoogeographic origins, showing the closest affinity with the Lusitanian-Mediterranean region. Very few apparent endemics were found (14\%), and only in part supported by consistent sampling. Coral diversity is particularly high between 300 and $900 \mathrm{~m}$ depths, in areas recognized as traditional fishing grounds or exploitable fish habitat within the 100-mile limit of the EEZ. The composition of coral assemblages shows significant geographical structure among longitudinal sections of the study area at comparable depths $(100-1500 \mathrm{~m})$. There is no evidence of a possible role of the Mid-Atlantic Ridge or latitudinal effects underlying this pattern, which suggests that it
\end{abstract}

may instead reflect assemblage variability among features. Stronger changes in species composition were found along the bathymetric gradient. Notwithstanding the mix of partially overlapping steno- and eurybathic species that characterize the vertical distribution of corals, there is a distinct transition from shallow $(100-600 \mathrm{~m})$ to intermediate $(600$ $1000 \mathrm{~m})$ depths. The analysis presented here constitutes a valuable contribution for efficient conservation policies of coral-associated vulnerable marine ecosystems and their sustainable use as fishing areas.

\section{Introduction}

Cold-water corals are currently recognized as vulnerable and worth conserving due to their slow growth (e.g. Sherwood and Edinger, 2009; Roark et al., 2009; Carreiro-Silva et al., 2013) and their important role as structural elements that enhance habitat complexity and heterogeneity (FAO, 2009; Buhl-Mortensen et al., 2010; OSPAR, 2010; Auster et al., 2011). Widely distributed throughout the world's oceans, they can be found on continental shelves and margins, edges and slopes of oceanic islands, seamounts, canyons and ridges (e.g. Cairns, 2007; Wareham and Edinger, 2007; Molodtsova et al., 2008; Mortensen et al., 2008; Reveillaud et al., 2008; Baker et al., 2012), especially in areas of high currents and/or enhanced suspended or re-suspended organic matter (Davies et al., 2009; Guinan et al., 2009).

Occupying an area of almost one million $\mathrm{km}^{2}$ in the northeast Atlantic, the exclusive economic zone (EEZ) of the Azores archipelago comprises a rich submarine topography 
reaching $5000 \mathrm{~m}$ depths. Calculations based on bathymetry data identified the presence of 63 large and 398 small seamount-like features in the area (Morato et al., 2008), thus making it suitable for corals.

Major oceanographic expeditions during the late nineteenth century and throughout the 1900s (e.g. Josephine, Challenger, Talisman, campaigns of the Prince Albert I of Monaco - PAM, Biaçores and Bartlett) were a rich source of coral records. Until recently, this information had been scattered throughout numerous reports and taxonomic publications lacking a common taxonomic nomenclature and often difficult to access. Hall-Spencer et al. (2007) launched an online database comprising part of the historical records from PAM and Biaçores campaigns regarding scleractinian, antipatharian and gorgonian taxa (exclusive of five families from the order Alcyonacea) found at depths $>200 \mathrm{~m}$. For the Azores, only 46 taxa were included in the database. A synthesis of all prior key campaigns and other available information on past coral records, covering a broader taxonomic range, is still lacking for the Azores. This step is essential to build a database that will enable investigating patterns of species distributions on a regional scale.

Ongoing efforts to map, describe and catalogue benthic communities of the Azores using video surveys are contributing to the discovery of coral gardens (Braga-Henriques et al., 2012; Tempera et al., 2012), providing inputs to the EUNIS European hierarchical biotope classification system (Galparsoro et al., 2012) and to the OSPAR Convention for the Protection of the Marine Environment of the North-East Atlantic (OSPAR, 2010). However, this information is spatially restricted due to logistical constraints and the high costs associated with deep sampling. In comparison, the combination of historical records with data from fisheries' by-catch and from occasional surveys can provide a more insightful picture of the diversity and distribution of corals in this region.

The main goal of this study is to assess the diversity, distribution and biogeographical patterns of corals belonging to orders Alcyonacea, Antipatharia and Scleractinia, and the hydrozoan family Stylasteridae in the Azores. Along with a brief account of the historical coral collection in the region since the mid-nineteenth century, we present an updated taxonomic inventory based on historical sources and unpublished data collected by the Centre of IMAR and Department of Oceanography and Fisheries of the University of the Azores in recent years. Georeferenced species records were used to map the distribution of the major taxonomic groups, and to estimate species richness at regional, local and bathymetric scales. Furthermore, we examined the spatial structure of coral assemblages by testing the hypotheses of no differences in the species lists among (1) feature types (island or seamount), (2) longitudinal sections of the EEZ and (3) depth intervals.

\section{Material and methods}

\subsection{Study area}

The Azores EEZ is located in the NE Atlantic near the triple junction of the North American, Eurasian and African plates between $33^{\circ} 46^{\prime} \mathrm{N}-42^{\circ} 57^{\prime} \mathrm{N}, 35^{\circ} 45^{\prime} \mathrm{W}-21^{\circ} 05^{\prime} \mathrm{W}$ (Fig. 1). It comprises nine volcanic islands of recent origin (Azevedo et al., 1991) with narrow shelves and steep slopes, spread along a NW-SE-trending strip $600 \mathrm{~km}$ long, with the MidAtlantic Ridge (MAR) separating the islands of Flores and Corvo, to the west, from the remaining island groups. $\mathrm{Nu}$ merous seamounts of very different size, shape and depth are scattered throughout the study area (Morato et al., 2008).

Ocean circulation patterns in the Azores are complex (Santos et al., 1995; Alves and Verdière, 1999; Johnson and Stevenson, 2000). Large-scale circulation is dominated by two eastward-flowing branches of the Gulf Stream: the cold North Atlantic Current (NAC) in the north, crossing the MAR between $45-48^{\circ} \mathrm{N}$ (Bower et al., 2002), and the warm Azores Current $(\mathrm{AzC})$ in the south, which crosses the MAR between $34-36^{\circ} \mathrm{N}$ (Alves and Verdière, 1999). One additional eastward flow can be traced between the NAC and the $\mathrm{AzC}$ around $39-42^{\circ} \mathrm{N}$ (Reverdin et al., 2003). Mesoscale eddies also occur on both sides of the AzC (Alves and Verdière, 1999). The Azores is a transitional region between subtropical and temperate climates. Sea temperature is characterized by horizontal gradients enhanced by the NAC and the $\mathrm{AzC}$ flows (Bashmashnikov et al., 2004).

\subsection{Review and compilation of coral data}

Historical and new coral records included specimens of the anthozoan orders Alcyonacea, Antipatharia and Scleractinia, and of the hydrozoan family Stylasteridae, which are the most commonly recorded taxonomic groups in the Azores showing habitat-forming features. In the scope of this study, one record is the occurrence of one or more individuals of any given taxon at a specific location. We have conducted an exhaustive review of the literature concerning major oceanographic expeditions (1869-1981) and other data sources for coral events pre-2012 (Table 1). Latitude, longitude, depth, campaign, station, taxonomic classification and abundance per taxon were gleaned to create a single database. Missing station number, geographical coordinates or depth were, whenever possible, assigned to each entry based on an exhaustive search of primary literature from other taxonomic groups (e.g. Talisman campaign, Billard, 1907). Synonyms were updated and chresonyms reviewed according to the published literature on coral taxonomy since the mid-nineteenth century until present day by leading taxonomic authorities in order to present the most accurate taxonomic nomenclature currently accepted. Regarding the CANCAP-V campaign and given that almost all coral data remain unpublished, we visited the collection of 


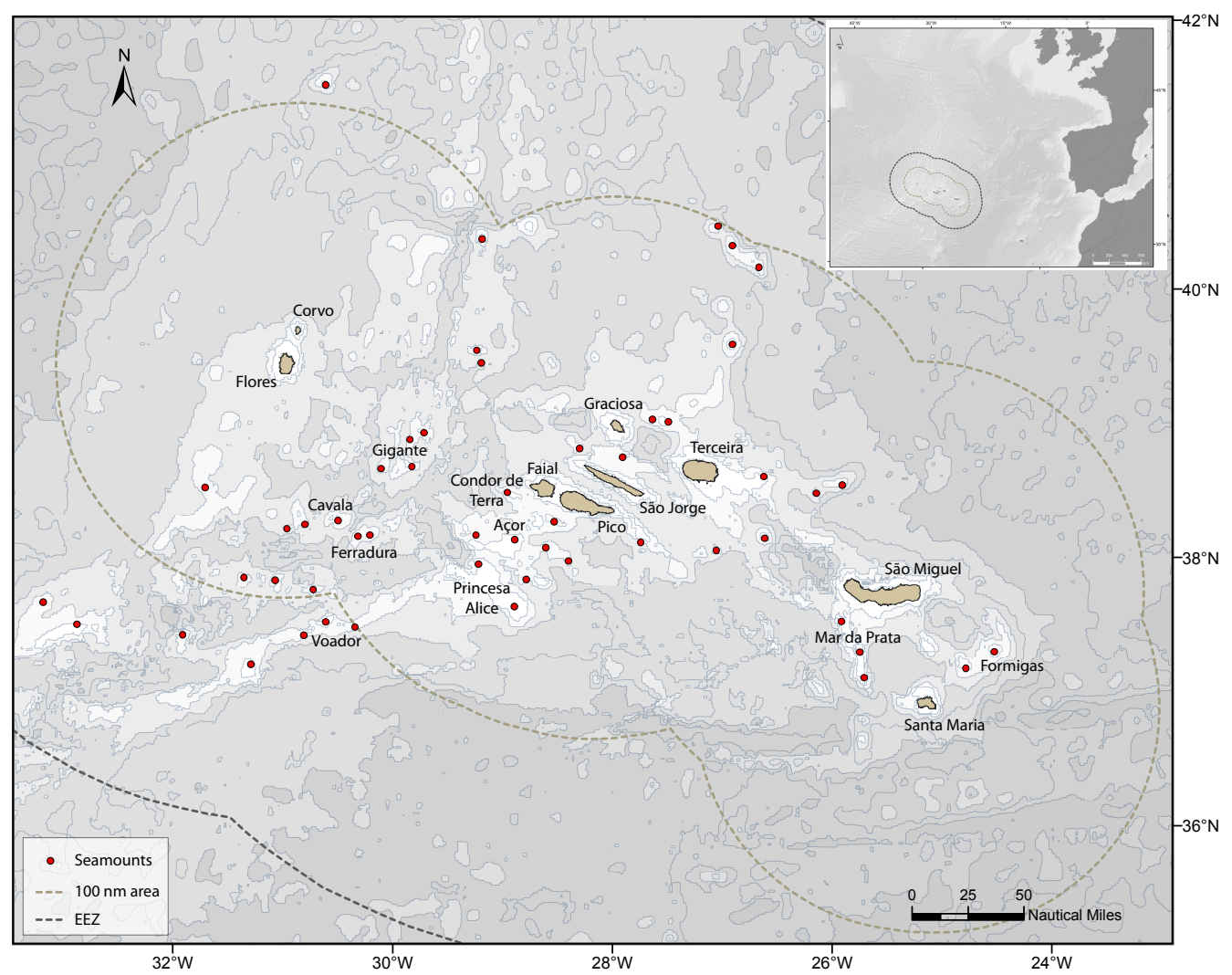

Fig. 1. Map of the study area showing the most important geomorphological features (islands and seamounts) sampled within the Azores EEZ.

the Naturalis Biodiversity Center Leiden to examine the Alcyonacea and part of the Scleractinia collections. We also included two coral records from material deposited at the IMAR-DOP/UAc reference collection based in Horta (Faial Island).

New coral records (hereafter designated as IMARDOP/UAc records) regard the period between 1980-2011 and were based on scientific expeditions, experimental fishing surveys and by-catch data from commercial longliners (Table 2). Corals were photographed, fixed and preserved mostly in $70 \%$ ethanol for later identification. In total, we examined 2066 specimens $(5-1700 \mathrm{~m})$. Sampling information for each specimen was recorded and added to the database.

Distinguishing morphological characters were used to identify specimens to the lowest possible taxon: gross morphology, branching pattern, polyp size, type and arrangement of sclerites - Alcyonacea (see Bayer et al., 1983); gross morphology, branching pattern, morphology and arrangement of polyps and axial spines - Antipatharia (see Opresko, 2006, and references therein); gross morphology, septal arrangement, presence or absence of columella - Scleractinia (see Zibrowius, 1980); and arrangement of the dactylopores and gastropores, presence or absence of gastro- and dactylostyles, cyclosystem orientation and coenosteal texture - Stylasteridae (see Cairns, 1991, and Zibrowius and
Cairns, 1992). A small proportion of our classifications (Dentomuricea aff. meteor, Leiopathes sp.A, Elatopathes aff. abietina) should be considered tentative given that these taxa are still under review. The studied material is deposited in the reference collection of the IMAR-DOP/UAc (COLETA).

\subsection{Data analysis}

Prior to treatment of data, we performed a number of quality checks. First, we verified sampling information of each georeferenced record in a GIS environment to exclude records without a positive match of all information (depth, locality name, geographical coordinates). Location of data points on island slopes was confirmed using the bathymetric layer from Lourenço et al. (1998). Confirmation of seamount positions was based on Morato et al. (2008). Second, we checked the most accurate sampling information available for each record and corrected inaccuracies detected among station numbers of the same campaign (e.g. typing errors). Historical records for which only start and end positions of the haul were available (nine stations from the PAM campaigns) were assigned to the midpoint coordinate. In these cases, we checked whether the trawl track (assuming a straight line between start and end positions) crossed different grid cells used for calculation of species richness, which was not the case. 
Table 1. Data sources for the coral records obtained during the major oceanographic expeditions between 1869-1981 and other events with sporadic records. References herein were also used in the nomenclature revision.

\begin{tabular}{|c|c|c|c|c|}
\hline Campaign & Year & Vessel/Vehicle & Sampling gear & Source \\
\hline Josephine & 1869 & RV Josephine & - & Lindström (1877), Aurivillius (1931), Zibrowius (1980), Bayer (1981) \\
\hline Challenger & 1873 & HMS Challenger & Dredge, trawling & Moseley (1881), Studer (1889), Wright and Studer (1889), Zibrowius (1980) \\
\hline Talisman & 1883 & RV Talisman & Dredge & $\begin{array}{l}\text { Gourret (1906), Hickson (1912), Boschma (1963), Zibrowius (1980), } \\
\text { Grasshoff (1986), Zibrowius and Cairns (1992) }\end{array}$ \\
\hline $\begin{array}{l}\text { Campaigns of } \\
\text { Prince Albert } \\
\text { I of } \\
\text { Monaco }\end{array}$ & $\begin{array}{l}1885-1888 \\
1895-1897 \\
1902-1905 \\
1911-1914\end{array}$ & $\begin{array}{l}\text { RV Hirondelle, } \\
\text { RV Princesse Alice, } \\
\text { RV Princesse Alice II, } \\
\text { RV Hirondelle II }\end{array}$ & $\begin{array}{l}\text { Barre à fauberts, } \\
\text { double traps, trammel } \\
\text { nets, traps, trawling }\end{array}$ & $\begin{array}{l}\text { Studer (1890, 1891, 1901), Jourdan (1895), Roule (1902, 1905), Calvet } \\
\text { (1903, 1911), Gravier (1915, 1920, 1921), Verril (1922), Thomson (1927), } \\
\text { Pax and Müller (1954), Grasshoff (1973, 1977, 1981, 1992), Zibrowius } \\
\text { (1980), Carpine and Grasshoff (1985), Weinberg (1990), Zibrowius and } \\
\text { Cairns (1992), Ocaña et al. (2000), Molodtsova (2006) }\end{array}$ \\
\hline Biaçores & 1971 & RV Jean Charcot & $\begin{array}{l}\text { Dredge, epibenthic } \\
\text { trawl, scuba diving }\end{array}$ & $\begin{array}{l}\text { Tixier-Durivault and d'Hondt (1975), Grasshoff (1977, 1982), Zibrowius } \\
\text { (1980), Zibrowius and Cairns (1992), Stokvis and van Ofwegen (2006) }\end{array}$ \\
\hline Bartlett & 1975 & USNS Bartlett & Dredge & Zibrowius (1980), Grasshoff (1981, 1982), Zibrowius and Cairns (1992) \\
\hline CANCAP-V & 1981 & HNIMS Tydeman & $\begin{array}{l}\text { Agassiz trawl, beam } \\
\text { triangular dredge, } \\
\text { trawl, rectangular and } \\
\text { van Veen grab }\end{array}$ & $\begin{array}{l}\text { Collection of information from Naturalis Biodiversity Center Leiden and IMAR- } \\
\text { DOP/University of the Azores, } \\
\text { collections of the Smithsonian National Museum of Natural History } \\
\text { (http://collections.si.edu/search/), Grasshoff (1992) }\end{array}$ \\
\hline Other & $1864-2011$ & $\begin{array}{l}\text { Submersibles } \\
\text { Archimède (CNEXO), } \\
\text { Nautile (IFREMER), } \\
\text { Lula (FRN); } \\
\text { ROVs Luso (EMEPC) and } \\
\text { SP (DOP/UAc); } \\
\text { commercial fishing } \\
\text { vessels }\end{array}$ & $\begin{array}{l}\text { Bottom longline, } \\
\text { dredge, grabbing, } \\
\text { bottom trawling, } \\
\text { scuba diving }\end{array}$ & $\begin{array}{l}\text { Verrill (1864), Pourtalès (1871), CNEXO (1972), Zibrowius and Saldanha } \\
\text { (1976), Zibrowius (1980), Bayer (1981), Carpine and Grasshoff (1985), } \\
\text { Zibrowius and Cairns (1992), López-González and Gili (2001), Stokvis and } \\
\text { van Ofwegen (2006), Ocaña et al. (2007), Sampaio et al. (2009), Braga- } \\
\text { Henriques et al. (2011), Carreiro-Silva et al. (2011), Braga-Henriques et al. } \\
\text { (2012), Sampaio et al. (2012), Tempera et al. (2012), de Matos et al. (2013) }\end{array}$ \\
\hline
\end{tabular}

Recent data from bottom longline scientific surveys were set up by depth strata of $50 \mathrm{~m}$. Therefore the spatial error associated with these records was negligible. Furthermore, in most cases the exact location of each coral collection was available and no midpoint coordinate was assigned. Records lacking the information regarding depth strata were eliminated from the study. As for records obtained by observers on the bottom longline commercial fleet, they also have accurate sampling information. Lastly, the majority of records assembled from the multiple sources presented a single value for depth (e.g. PAM, Challenger). When this was not the case, midpoint depths were calculated for records with depth intervals $\leq 350 \mathrm{~m}$. Records with wider depth ranges were excluded from the data set. The only exception to this procedure consisted of four deep stations from CANCAP-V, one from Bartlett and one from the CENTOB-cruise Marvel, which included unique records for some species and/or depth ranges. Nevertheless, those records were not included in the data set used for multivariate analysis to detect spatial trends in assemblage composition.

\subsubsection{Distribution and species richness}

Distribution maps were plotted based on all georeferenced records available for each taxonomic group (Alcyonacea, Antipatharia, Scleractinia and Stylasteridae). To identify potential hotspots of coral diversity, species richness was calculated in $20 \mathrm{~km} \times 20 \mathrm{~km}$ grid cells using XTools Pro 9.0 for ArcMap and R (R Development Core Team, 2011). The vertical distribution of individual species was also computed to assess bathymetric profiles of species richness for each taxonomic group and all groups combined. Depth data were based on the actual information stated in the original sources, and none were inferred from their location using GIS bathymetric layers. Species accumulation curves and $95 \%$ confidence intervals based on incidence (presence/absence) of species by sample were estimated using the Mao Tau indicator of expected species richness in EstimateS 8.0 (Colwell, 2006). To minimize possible bias due to the inherent differences in sampled areas between gear types (Colwell et al., 2004), we calculated accumulation curves separately for trawled (trawls, dredges, etc.) and longline gears.

\subsubsection{Spatial trends in assemblage composition}

The geographical and bathymetric structure of coral assemblages was investigated using multivariate analysis with the software package PRIMER-E v.6.1.6 (Clarke and Gorley, 2006). Records were assigned to a specific geomorphic feature (oceanic island or seamount) whenever their position was on that feature (verified using GIS) or, if sampling coordinates were missing, when there was specific mention of the feature name. The available data set spanning nine islands and 36 seamounts and depths from 5 to $1830 \mathrm{~m}$ was restricted to $100-1500 \mathrm{~m}$ to ensure a common bathymetric range of sampling across features. Furthermore, sample-poor features 
Table 2. Source details for coral IMAR-DOP/UAc records collected in the Azores EEZ.

\begin{tabular}{|c|c|c|c|c|}
\hline Campaign & Date & Vessel & Gear & No. of individuals \\
\hline ARQDAÇO & $\begin{array}{l}1995, \\
2004-2005, \\
2007-2008, \\
2010-2011\end{array}$ & RV Arquipélago & Bottom longline & 473 \\
\hline ASIMOV & 2000 & RV Águas Vivas & Scuba diving & 1 \\
\hline Bancos & 2007 & RV Arquipélago & Scuba diving & 4 \\
\hline BIO-FAPI 3 & 2003 & RV Arquipélago & Dredge & 1 \\
\hline Chaceon affinis & 2003 & FV Garcia Miguel & Baited traps & 10 \\
\hline CONDOR & 2009-2010 & RV Arquipélago & Bottom longline, traps & 171 \\
\hline CoralFISH/Açores & 2010 & $\begin{array}{l}\text { NRP Almirante } \\
\text { Gago Coutinho }\end{array}$ & ROV Luso & 20 \\
\hline CoralFISH/Faial-Pico channel & 2011 & RV Águas Vivas & ROV SP & 4 \\
\hline CoralFishID & 2010-2011 & RV Arquipélago & Bottom longline & 130 \\
\hline CORAZON & 2009 & Ada Rebikoff & Submersible Lula & 7 \\
\hline DEECON & 2007 & RV Arquipélago & Bottom longline & 15 \\
\hline Defending our Oceans/Greenpeace & 2006 & MV Esperanza & Towed camera & 9 \\
\hline EMAM/PEPC_M@rBis & 2011 & NTM Creoula & Scuba diving & 2 \\
\hline EMEPC/LUSO/Açores & 2009 & $\begin{array}{l}\text { NRP Almirante } \\
\text { Gago Coutinho }\end{array}$ & ROV Luso & 1 \\
\hline EMEPC/LUSO/Açores G3 & 2008 & $\begin{array}{l}\text { NRP Almirante } \\
\text { Gago Coutinho }\end{array}$ & ROV Luso & 11 \\
\hline EMPAFISH & 2005 & RV Arquipélago & Bottom longline & 3 \\
\hline FAIVI/IOZ & 2011 & RV L'Atalante & - & 28 \\
\hline FISHOR & 2002 & FV Pakura & Bottom trawling & 19 \\
\hline LusoExpedição & 2007 & NTM Creoula & Scuba diving & 17 \\
\hline MARPROF-Crustaço & 2009-2011 & RV Arquipélago & Traps & 13 \\
\hline METEOR-58/3 & 2003 & RV Meteor & ROV Quest & 2 \\
\hline Observers & $\begin{array}{l}1980, \\
1982,1990, \\
2002-2011\end{array}$ & $\begin{array}{l}\text { Commercial } \\
\text { fishing vessels }\end{array}$ & Bottom longline, handline & 1030 \\
\hline PESCPROF & 2004-2005 & RV Arquipélago & Bottom longline & 13 \\
\hline SEAHMA & 2002 & RV L'Atalante & ROV Victor & 1 \\
\hline Other & - & - & - & 81 \\
\hline
\end{tabular}

with less than 10 species were discarded from the analysis because these would become outliers and cause the collapse of ordination plots (Clarke et al., 2006). The resulting data set after the above treatment comprised 131 species distributed among 493 samples and 18 features (Table 3). Because of the variety of data sources and collection gears used, abundance values were not comparable. Therefore records were reduced to presence/absence.

To assess whether discrepancies in sampling effort among features (varying between 8 and 76 samples, with an overall median of 22) had a significant influence on the observed patterns, we used Spearman's correlation coefficient and the RELATE routine implemented in PRIMER-E. Using the Bray-Curtis similarity coefficient, a similarity matrix calculated from the entire data set was correlated with simulated matrices in which the maximum sampling effort per feature was limited to the median number of samples overall. This procedure was repeated 10 times with different sets of samples randomly chosen for features exceeding that num- ber. The Spearman correlation coefficient was consistently high $(r=0.804, \mathrm{SD}=0.004)$ and statistically significant in all cases $(P<0.01)$, indicating that the multivariate patterns obtained with fully and partially sampled features were similar. Thus, all subsequent analyses were done using the entire set of samples.

Non-metric multidimensional scaling (nMDS) ordination was performed to visualize spatial gradients in coral assemblages. Analyses of similarities (ANOSIM) were used to test for significant differences in coral assemblages among (1) feature types, (2) longitudinal sections of the EEZ and (3) depth intervals. Feature type had two levels (islands and seamounts), longitudinal section had three levels based on the relative position of the MAR and island groups (western, comprising the area west of the MAR and seamounts on the MAR; central, located east of the MAR until $26^{\circ} 30^{\prime} \mathrm{W}$; and eastern, encompassing the area east of $26^{\circ} 30^{\prime} \mathrm{W}$ ), and depth interval had three levels (shallow, 100-600 m; intermediate, 600-1000 m; and deep, 1000-1500 m). In all cases, $P$ values 
Table 3. List of features selected for biogeographic analysis of coral fauna. Numbers refer to the samples used (between 100-1500 m) and do not include the total number of records available.

\begin{tabular}{lllccccc}
\hline Section & Feature & Feature name & $\begin{array}{c}\text { No. of } \\
\text { samples }\end{array}$ & $\begin{array}{c}\text { No. of } \\
\text { species }\end{array}$ & $\begin{array}{c}\text { Mean } \\
\text { depth (m) }\end{array}$ & $\begin{array}{c}\text { Min. } \\
\text { depth (m) }\end{array}$ & $\begin{array}{c}\text { Max. } \\
\text { depth (m) }\end{array}$ \\
\hline \multirow{6}{*}{ Western } & Island & Flores & 31 & 47 & 662 & 104 & 1406 \\
& Seamount & Gigante & 20 & 21 & 424 & 196 & 1331 \\
& Seamount & Cavala & 11 & 13 & 401 & 212 & 775 \\
& Island & Corvo & 8 & 17 & 699 & 142 & 1424 \\
& Seamount & Ferradura & 8 & 15 & 551 & 357 & 800 \\
\hline \multirow{6}{*}{ Central } & Seamount & Açor & 76 & 41 & 419 & 165 & 1350 \\
& Seamount & Princesa Alice & 75 & 32 & 347 & 146 & 1500 \\
& Seamount & Condor de Terra & 54 & 27 & 343 & 120 & 1269 \\
& Island & Faial & 24 & 25 & 588 & 110 & 1500 \\
& Island & Terceira & 23 & 45 & 551 & 114 & 1165 \\
& Island & São Jorge & 23 & 44 & 1049 & 105 & 1340 \\
& Island & Pico & 22 & 33 & 658 & 131 & 1455 \\
& Island & Graciosa & 15 & 27 & 486 & 109 & 1455 \\
& Seamount & Voador & 15 & 19 & 432 & 216 & 1264 \\
\hline \multirow{6}{*}{ Eastern } & Island & São Miguel & 46 & 64 & 737 & 103 & 1494 \\
& Seamount & Mar da Prata & 20 & 35 & 409 & 157 & 1378 \\
& Island & Santa Maria & 12 & 30 & 680 & 122 & 1495 \\
& Seamount & Formigas & 9 & 16 & 605 & 140 & 1315 \\
\hline
\end{tabular}

were calculated using 5000 permutations. First, we tested for differences among islands and seamounts by means of a twoway crossed ANOSIM of feature type against the combination of longitudinal section and depth interval to remove all effects of these two factors. Global $R$ for feature type was not significant $(R=0.153, P=0.065)$, so a two-way crossed ANOSIM was performed to test for differences among longitudinal sections and depth intervals not considering feature type. To identify those taxa contributing the most to the observed dissimilarities among longitudinal sections and depth intervals, we used similarity percentages (SIMPER) analysis following the ANOSIM design. Species were ranked according to their average contribution to the total between-group average dissimilarity and the ratio of average to standard deviation of their contribution, which is a useful measure for species with high discriminating power.

\section{Results}

\subsection{Historical review}

To our knowledge, Verrill (1864) provided the first coral records from the Azores, namely Callogorgia verticillata, Viminella flagellum and Errina aspera (although the latter was in fact Errina dabneyi according to Zibrowius and Cairns, 1992). Specimens were collected around Faial Island, most likely by local fisherman, and donated to the Museum of Comparative Zoology (Cambridge, USA) by Charles Dabney.
The number of records would greatly increase in the following decades as a result of a period of heightened discovery in the deep sea that ran from approximately 1855 to 1931 , when major oceanographic expeditions conducted throughout the North Atlantic investigated the epibenthic fauna. The Josephine (1869), the Challenger (1873) and the Talisman (1883) were the first scientific expeditions to sample corals in the Azores. Josephine and Challenger documented 10 and 11 species, respectively. The highest coral richness was, however, obtained from the Talisman campaign, on which 14 species were collected from the 26 dredges made in the Azores at depths between 80 and $4415 \mathrm{~m}$. None of these campaigns recorded antipatharian species, and stylasterids were only reported from the Talisman expedition.

The next major surveys undertaken in the region started two years after the Talisman expedition and continued during the early twentieth century. On board the research vessels Hirondelle (1885-1888), Princesse Alice (1895-1897), Princesse Alice II (1902-1905) and Hirondelle II (1911-1914), Prince Albert I of Monaco and his team undertook 13 expeditions in the region. Multiple types of bottom gear (e.g. trawling, barre à fauberts, longline, traps, nets) were used to sample 879 stations distributed throughout the nine insular slopes, the seamounts Açor, Princesa Alice and Mar da Prata, as well as the Hirondelle Basin. As a result of these expeditions, 103 species were reported comprising 46 alcyonaceans, 14 antipatharians, 36 scleractinians and 7 stylasterids (see Table 1 and references therein), providing a major input to the knowledge of the coral fauna in the Azores. 
From then on, the number of coral occurrences continued to increase, showing a new pulse during the 1970s and early 1980s as a result of the Biaçores and Bartlett expeditions. At least 142 stations were sampled within the Azores EEZ under the Biaçores campaign carried out with RV Jean Charcot in 1971. Forty-one octocorals were recorded, seven of which were described for the first time (Tixier-Durivault and d'Hondt, 1975). Zibrowius (1980) also listed 52 scleractinians, describing five new species. The stylasterid material consisted of eight species collected in 20 stations (plus one non-georeferenced station) covering a bathymetric range between 380 and $1310 \mathrm{~m}$ depths (Zibrowius and Cairns, 1992). In 1975, the geological team from the USNS Bartlett investigated the diversity and distribution of the benthic fauna across an area in the Mid-Atlantic Ridge southwest of the Azores archipelago, within the EEZ of the Azores (total of 12 stations). In all, 14 alcyonaceans (Grasshoff, 1981), 15 scleractinians belonging to 8 genera (Zibrowius, 1980) and 3 stylasterids were identified (Zibrowius and Cairns, 1992).

Our final major source of historical occurrences was the CANCAP-V expedition with HNIMS Tydeman (May/June 1981), during which 192 bottom stations were sampled in the vicinity of the three island groups using gears such as Agassiz trawl, beam trawl, rectangular and triangular dredge, and van Veen grab (van der Land, 1987). We now report a coral collection deposited at the Naturalis Biodiversity Center in Leiden of at least 144 specimens belonging to 10 different families. This collection contains 19 alcyonacean and 8 scleractinian species collected from 41 stations (55-3150 m). Additional records of antipatharians are also listed in the museum database of the Smithsonian National Museum of Natural History (http://collections.si.edu/search/), increasing the CANCAP-V inventory to at least 32 coral species.

Since this campaign new species records have been described: Scyphopodium ingolfi (Bayer, 1981), Azoriella bayeri (López-González and Gili, 2001), Alcyonium profundum (Stokvis and van Ofwegen, 2006), Corallium niobe (Sampaio et al., 2009) and Antipathella subpinnata (de Matos et al., 2013). Video surveys conducted in the Azores showed evidence of rich coral communities; however, these did not document new records or describe new species (e.g. BragaHenriques et al., 2012; Tempera et al., 2012). In addition, observations with the submersible Archimède in 1969 usually refer to common names such as gorgonians or antipatharians, and many recognized taxa are reported with question marks (CNEXO, 1972).

\subsection{Taxonomy of new records}

Of all the specimens examined, 1575 were identified to species level, 270 to genus level and 125 to family level. Alcyonaceans accounted for the majority of the individuals $(56.6 \%)$ followed by scleractinians $(24.2 \%)$, antipatharians $(10.2 \%)$ and stylasterids $(9.0 \%)$. Out of 157 species compiled from the literature, we identified 61 in the IMAR-
DOP/UAc records. In addition, we now report nine new species records for the Azores (see Supplement for sampling details): Alcyonium maristenebrosi (Alcyonacea: Alcyoniidae), Alcyonium rubrum (Alcyonacea: Alcyoniidae), Paragorgia johnsoni (Alcyonacea: Paragorgiidae), D. aff. meteor (Alcyonacea: Plexauridae), Lepidisis cyanae (Alcyonacea: Isididae), Leiopathes sp.A (Antipatharia: Leiopathidae), Distichopathes sp. (Antipatharia: Aphanipathidae), Coenocyathus cylindricus (Scleractinia: Caryophylliidae) and Dendrophyllia ramea (Scleractinia: Dendrophylliidae).

\subsection{Distribution and species richness}

The combination of historical and IMAR-DOP/UAc records resulted in a database containing 2501 entries, $88 \%$ of which are georeferenced and comprise 1128 records of Alcyonacea, 744 of Scleractinia, 185 of Stylasteridae and 151 of Antipatharia. The updated inventory for the Azores EEZ now accounts for a total of 164 species, comprising 79 alcyonaceans (15 families), 18 antipatharians (5 families), 58 scleractinians (10 families) and 9 stylasterids (see Appendix A, Table A1). Approximately $30 \%$ of the species were represented by one or two records, while only $19 \%$ of them contributed 20 records or more (Fig. 2). The most common species by number of records were $V$. flagellum (120 records), C. verticillata (116), D. aff. meteor (106), E. dabneyi (85), Caryophyllia (Caryophyllia) cyathus (75), Madrepora oculata (72), Acanthogorgia armata (66) and Lophelia pertusa (64).

Despite the considerable discrepancy between taxonomic groups in the number of species and data points available, distribution patterns showed similar centres of diversity for all groups (Fig. 3). Corals were mostly found around islands and on nearby seamounts, especially those located southwest of Faial and south of São Miguel, with very few records falling outside the 100-mile limit of the EEZ and the Azores plateau. Spatial patterns of species richness broadly reflect the collection effort and revealed that areas of high taxonomic diversity ( $>20$ species) are found widespread throughout the archipelago (Fig. 4). By feature, species richness ranged from one species at several poorly sampled seamounts to 73 species (157 records) at São Miguel Island.

Species accumulation curves indicate that the regional coral fauna is relatively well sampled regardless of the type of gear used (Fig. 5). The curve corresponding to longline data quickly reached a state of near saturation, indicating that the addition of new species was slow after the most common ones had been sampled. In contrast, the curve calculated from trawled gears samples grew steeper as a result of the greater area sampled per haul compared to longlines. Although an asymptote has not yet been reached in both cases, it is unlikely that further sampling of the habitats already surveyed will lead to the discovery of more than a few rare species.

The data set covered a broad bathymetric range $(5-3215 \mathrm{~m})$. Some species, such as Acanella arbuscula 


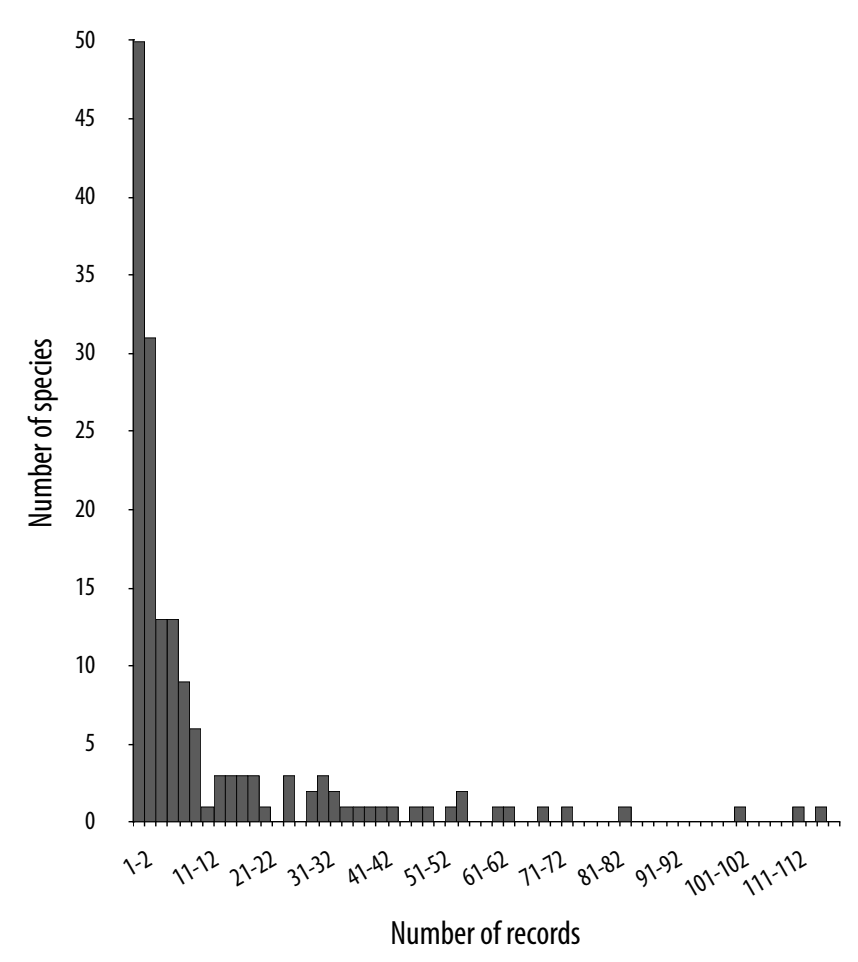

Fig. 2. Distribution of number of species per number of records.

Table 4. Results of the two-way crossed ANOSIM test based on similarity matrix derived from presence/absence data. (a) Global tests on the effect of longitudinal section and depth interval; (b) pairwise tests averaged across all section groups and across all depth groups. All results are significant $(P \leq 0.05)$.

\begin{tabular}{cccccc}
\hline \multicolumn{5}{c}{ (a) Source of variation } \\
\hline \multicolumn{7}{c}{ Longitudinal section } & \multicolumn{3}{c}{ Depth interval } \\
Global $R$ & $P$ & Global $R$ & $P$ \\
0.253 & 0.000 & 0.432 & 0.000 \\
\hline \multicolumn{5}{c}{ (b) Source of variation } \\
\hline \multicolumn{5}{c}{ Longitudinal section } \\
Western vs. Central & Western vs. Eastern & Central vs. Eastern \\
$R$ & $P$ & $R$ & $P$ & $R$ & $P$ \\
0.270 & 0.003 & 0.201 & 0.039 & 0.263 & 0.006 \\
\multicolumn{5}{c}{ Depth interval } \\
Shallow vs. Intermediate & Shallow vs. Deep & Intermediate vs. Deep \\
$R$ & $P$ & $R$ & $P$ & $R$ & $P$ \\
0.506 & 0.000 & 0.549 & 0.000 & 0.166 & 0.007 \\
\hline \multicolumn{5}{c}{}
\end{tabular}

(815-3100 m) and Solenosmilia variabilis (424-2050 m), showed broad depth distributions, while others occurred within narrow depth ranges, as was the case of the deep bathyal species A. profundum (2200-2600 m) and Flabellum (Ulocyathus) angulare (2085-2720 m), or Paracalyptrophora josephinae (200-624 m) and Dasmosmilia lymani (142-230 m) at shallower depths (see Appendix A, Fig. A1, for individual depth ranges of all species).

The bulk of records were concentrated at upper bathyal depths, between 100-600 m, while the highest diversity oc- curred between 300 and $900 \mathrm{~m}$ depths, reaching its peak at 500-600 m with 59 species from all groups (Fig. 6). Maximum diversity occurred at different depths for each group: $500-600 \mathrm{~m}$ for Alcyonacea (29 species); $400-500 \mathrm{~m}$ for Antipatharia (seven species); $500-600 \mathrm{~m}$ and $700-800 \mathrm{~m}$ for Scleractinia (24 species); 800-1000 m for Stylasteridae (six species). We found a marked decrease in species richness below $2200 \mathrm{~m}$, which was coincident with a scarcity of records. Stylasterids were absent at these greater depths, and the other groups were represented by 10 alcyonacean, two antipatharian and four scleractinian species.

\subsection{Multivariate analysis of community structure}

Two-way crossed ANOSIM revealed statistically significant gradients in assemblage composition among longitudinal sections averaged across depth intervals (global $R=0.253$; $P=0.000)$ and among depth intervals averaged across longitudinal sections of the study area (global $R=0.413$; $P=0.000$ ). Pairwise comparisons among levels for each factor were all statistically significant (Table 4). The higher global $R$ value obtained for depth indicates that this effect had the strongest contribution to the overall trend. On the other hand, the existence of a longitudinal gradient should be interpreted with caution given the low global $R$ value for this factor. These results were reflected on the nMDS ordination (Fig. 7). The depth gradient was particularly evident, with shallower assemblages $(100-600 \mathrm{~m})$ clustered on the upper right side of the plot, the deepest ones (1000-1500 m) scattered below and to the left, and those from intermediate depths $(600-1000 \mathrm{~m})$ placed roughly in between, although considerably interspersed with the deep assemblages. A longitudinal gradient was less obvious in the ordination, as expected given the results of ANOSIM.

According to the SIMPER analysis, the average dissimilarity among longitudinal sections was $80.13 \%$ for western vs. central, $85.45 \%$ for western vs. eastern and $79.02 \%$ for central vs. eastern. The number of species accounting for $50 \%$ of the difference between sections ranged between 23 and 26. However, none were good discriminators; that is, their ratio of average dissimilarity to standard deviation was always lower than 1.3 (Appendix A, Table A2). Among depth intervals, average dissimilarity was $83.36 \%$ for shallow vs. intermediate, $92.52 \%$ for shallow vs. deep and $86.13 \%$ for intermediate vs. deep. As in the previous case individual contributions to dissimilarity patterns were low $(<4.9 \%)$, although, when comparing the shallow and deep intervals, it was possible to identify three good discriminating species: $V$. flagellum, C. cyathus and C. verticillata. These were consistently found in shallower assemblages and virtually absent from the deepest habitats (only V. flagellum was recorded at $1187 \mathrm{~m}$ depth, and only once). Other species were also absent from deep assemblages (e.g. Schizophytum echinatum, Villogorgia bebrycoides, D. aff. meteor) but contributed less consistently to dissimilarity patterns because of the lower 

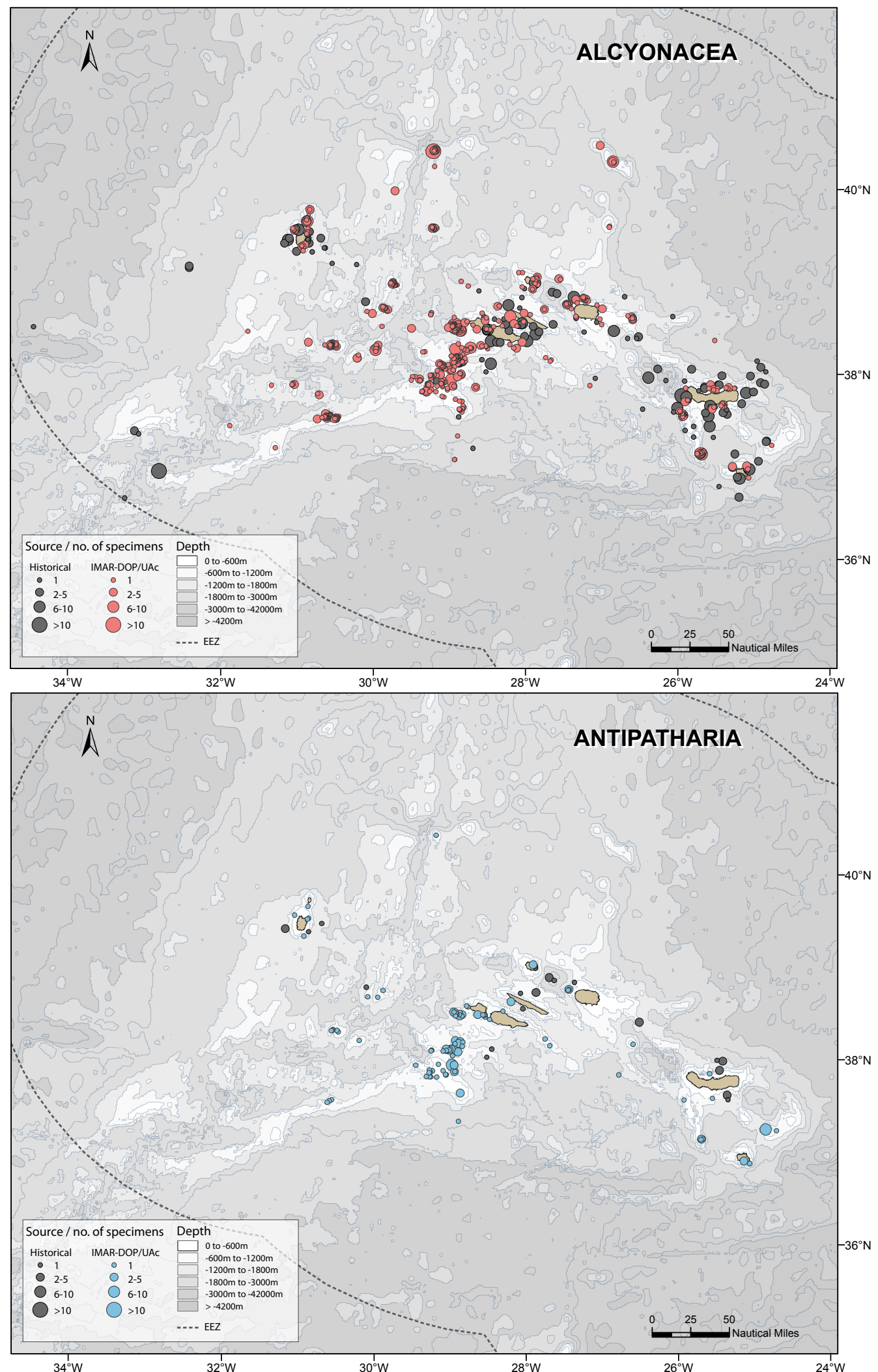

Fig. 3. Distribution of georeferenced coral records per taxonomic group for the Azores EEZ based on major oceanographic expeditions, other coral events and IMAR-DOP/UAc records, from 1869 to 2011. Alcyonacea: 299 historical/829 IMAR-DOP/UAc records; Antipatharia: 31/120; Scleractinia: 417/327; Stylasteridae: 60/125. 


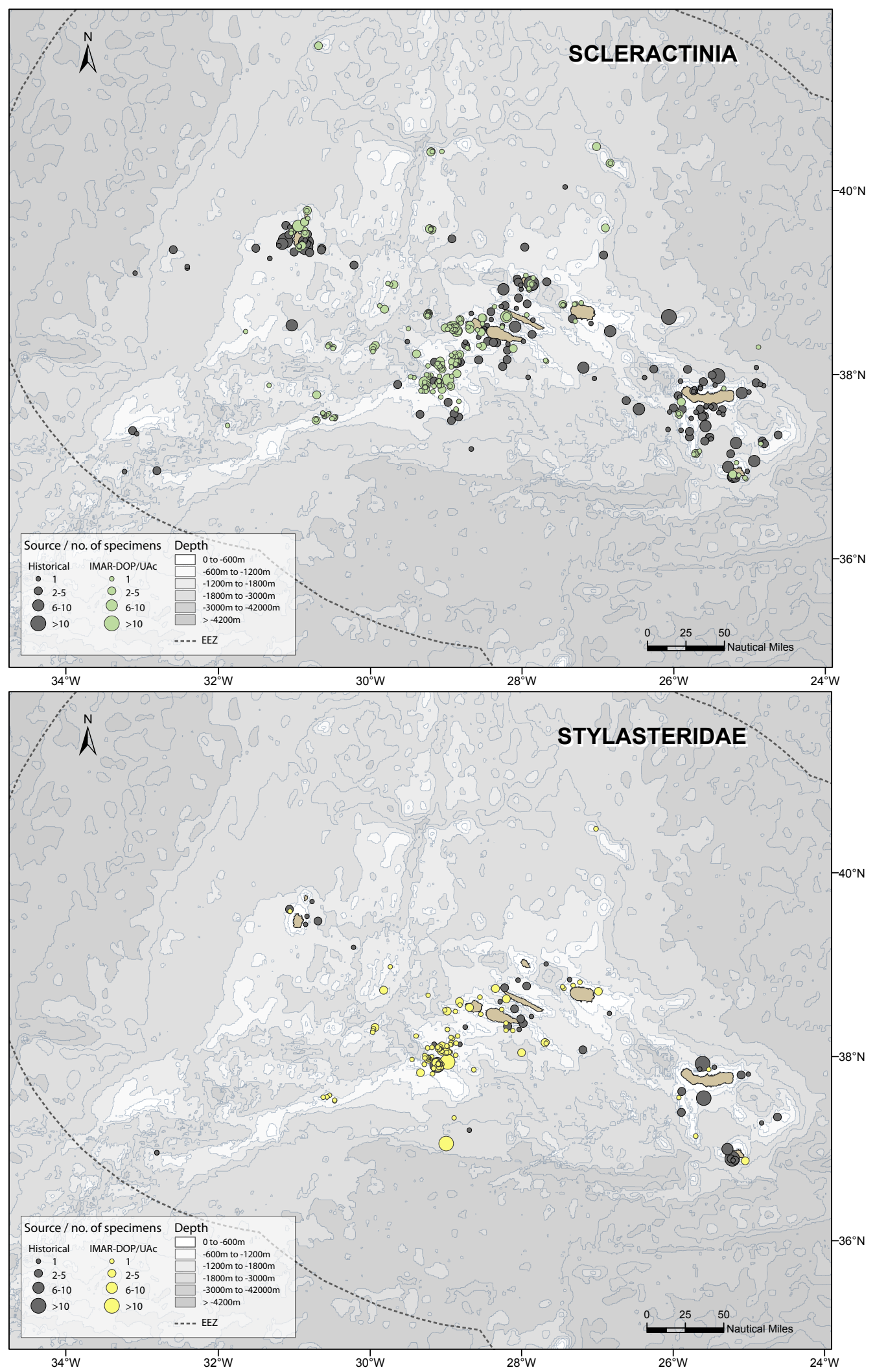

Fig. 3 . Continued. 

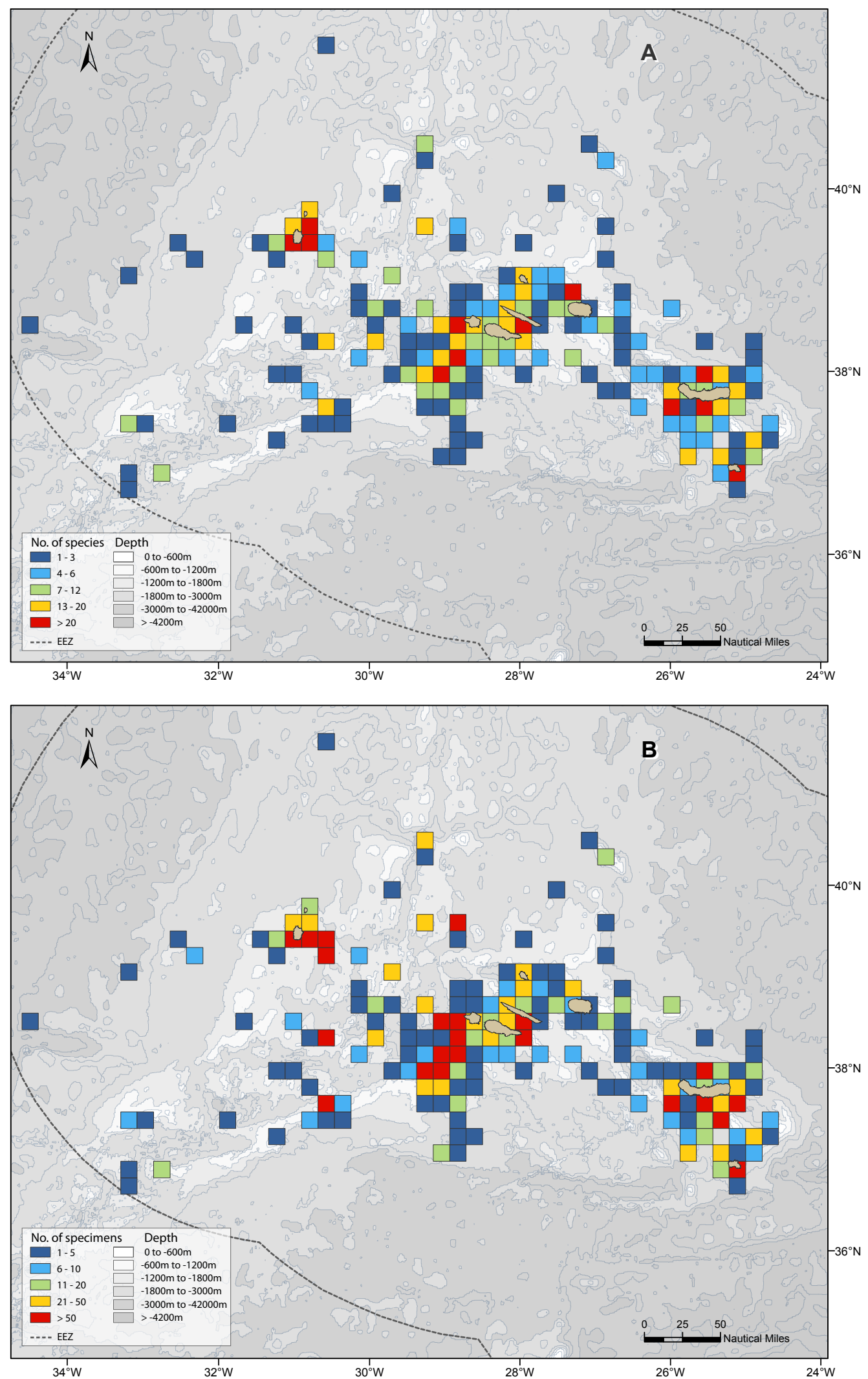

Fig. 4 . Species diversity of corals in the Azores EEZ per $20 \mathrm{~km} \times 20 \mathrm{~km}$ cells. (A) Number of species; (B) number of specimens. Samples comprised 164 species belonging to Alcyonacea, Antipatharia, Scleractinia and Stylasteridae. 


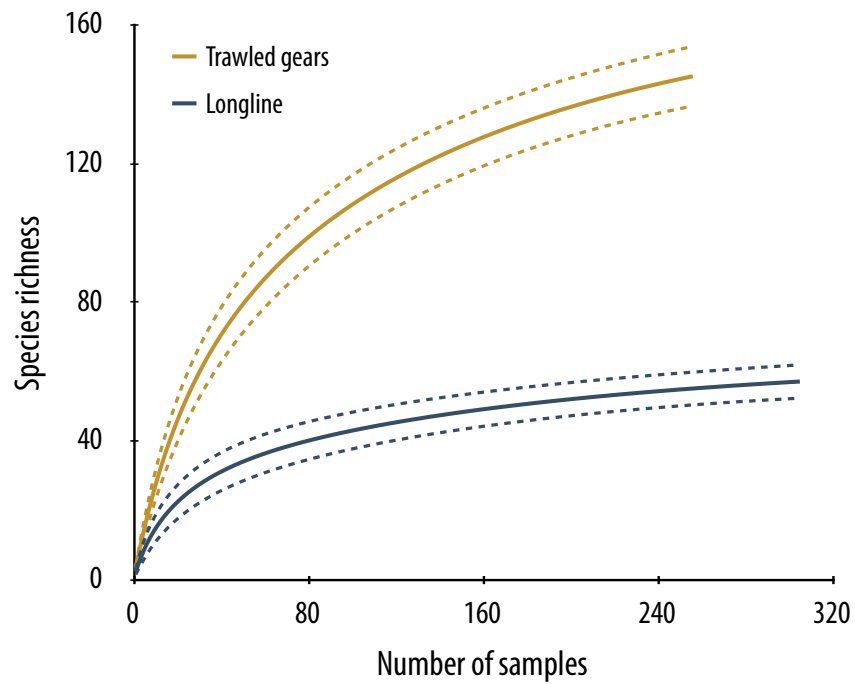

Fig. 5 . Sample-based rarefaction curves for coral fauna by trawled and bottom longline gears. Expected species richness values were calculated using the Mao Tau moment-based estimator with $95 \%$ confidence intervals (dashed lines).

geographical coverage of their records in comparison to the above species. For the same reason, several species that were absent from the shallow depth range (e.g. Stephanocyathus (Stephanocyathus) moseleyanus, A. arbuscula, Flabellum (Ulocyathus) alabastrum) did not contribute as much to the dissimilarity between shallow and deep assemblages.

\section{Discussion}

To our knowledge, the data presented here constitute the most comprehensive biogeographical database yet created on a regional coral fauna of the northeast Atlantic. Research conducted at IMAR-DOP/UAc since the mid-2000s using bycatch and occasional collection has led to an almost twofold increment in the number of georeferenced occurrences for corals, greatly increasing the spatial coverage of distributional data and the material available for taxonomic studies. Even though the newly collected specimens were largely assigned to species that had already been reported in the literature, their examination improved our knowledge of the coral diversity in the region, extending the known geographical distribution of nine species to the Azores. Judging from the species accumulation curves, the updated species inventory here presented seems fairly complete. Nonetheless, based on the poorer sampling of habitats deeper than $1500 \mathrm{~m}$, this list is likely to grow with species typical of greater depths. Additionally, once the uncertain taxonomic status of a few specimens is clarified more species may be added. Coral taxonomy is complex, especially within certain groups for which some morphological descriptions lack sufficient clarity to distinguish between different states of a character, and oth- ers are based on limited material (e.g. Sarcodictyon charcoti, Titanideum obscurum, Thesea rigida) and may not cover the entire range of intraspecific morphological variability. The use of molecular tools may thus prove to be essential in assisting classical taxonomy in the discrimination between closely related species in these problematic groups (McFadden et al., 2011).

\subsection{Species composition}

The order Alcyonacea presented the highest diversity of species and number of records, suggesting that this is the dominant coral group in the Azores. However, we should consider the possibility of a negative sampling bias of solitary scleractinians in IMAR-DOP/UAc records. Historical surveys were mainly conducted with the use of trawled gears, whereas the recent records were based mostly on bottom longline. While the first are non-selective, the latter is less efficient for sampling solitary scleractinians than generally larger colonial species that possess more complex shapes (e.g. arborescent, bottlebrush, lyriform, reticulate). A recent 4-month survey of the by-catch from commercial longline fishery based at Horta revealed that the most frequently landed taxa were Leiopathes spp., E. dabneyi and Dendrophyllia sp., all possessing three-dimensional branched shapes (Sampaio et al., 2012). In the same survey, solitary scleractinians were all collected as secondary bycatch. Thus, notwithstanding the inevitable geographical and vertical heterogeneity of sampling effort present in our data set, the relative proportions among taxa are likely to provide a good representation of the coral fauna in the Azores, perhaps with the exception of solitary scleractinians.

\subsection{Species distribution and richness}

The distribution of corals was mainly clustered around insular slopes and on the edges and peaks of seamounts, in particular those located south of Faial Island (Açor, Princesa Alice and Condor de Terra) and south of São Miguel (Mar da Prata). These findings are in line with the known habitat requirements for most coral species, namely the presence of hard substrates with high topographic relief (Genin et al., 1986; Mortensen and Buhl-Mortensen, 2004; Guinan et al., 2009; Tong et al., 2012), low levels of sedimentation (Roberts et al., 2006), enhanced current flow (Frederiksen et al., 1992; Mienis et al., 2007; Dorschel et al., 2007) and high food supply (Bryan and Metaxas, 2007; Davies et al., 2009).

Coral observations were strongly linked with traditional fishing grounds within the 100-mile EEZ. Maximum species richness was achieved within the exploitable fish habitat, which is restricted to depths $<600 \mathrm{~m}$ and corresponds to about $1 \%$ of the EEZ (Menezes, 2003). Important areas for fisheries were identified as hotspots of coral diversity, such as the Açor (51 species recorded), Mar da Prata (41 species) and Princesa Alice (32 species) seamounts. Our observations are 


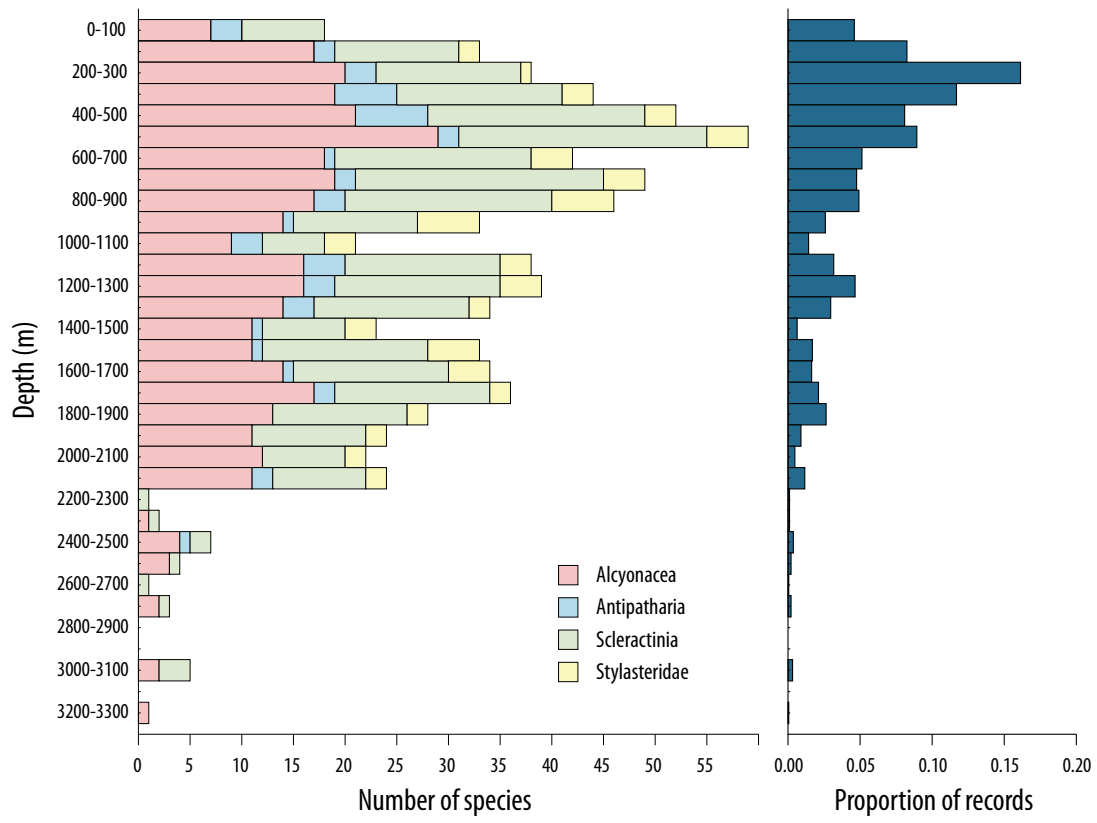

Fig. 6 . Summary of depth ranges for Alcyonacea, Antipatharia, Scleractinia and Stylasteridae.

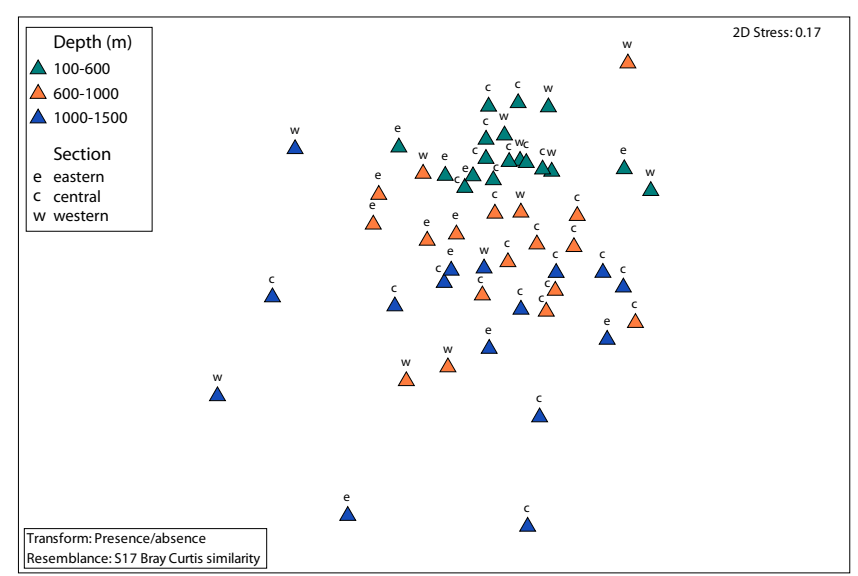

Fig. 7 . Non-metric multidimensional scaling ordination based on Bray-Curtis similarity coefficients for presence/absence data for features subdivided by depth intervals.

in agreement with previous studies suggesting an important role of cold-water coral communities as habitat providers for numerous fish and invertebrates (Husebø et al., 2002; BuhlMortensen et al., 2010; Söffker et al., 2011; Baillon et al., 2012; Braga-Henriques et al., 2012), favouring the aggregation of commercial species and increased local productivity. A full understanding of the degree of interaction between those communities and fisheries will require further studies combining coral distribution data and estimates of fishing effort for the region.

\subsection{Endemism and zoogeographic affinities}

Previous studies supported the proposition that isolation among seamounts promotes high rates of speciation and endemism (Richer de Forges et al., 2000; Koslow et al., 2001; Stocks and Hart, 2007). This prediction is being currently challenged by increasing reports of seamount megafaunas characterized by species with broad geographical distributions and few endemics (e.g. Samadi et al., 2006; O'Hara, 2007; McClain et al., 2009a), including coral assemblages in the North Atlantic (Cairns and Chapman, 2001; Thoma et al., 2009). Our study is in agreement with the latter given that the Azores region hosts a coral fauna of mixed zoogeographic affinities and only 23 of the 164 species (14\%) are apparent endemics (Table 5). It is, however, worth noting that only eight of these were consistently sampled throughout the study area (none were restricted to a unique feature), making conclusions regarding their regional endemicity more robust than for the remaining taxa, the vast majority of which were only recorded once. In the case of these rare species, it is for now impossible to tease apart potential endemicity from an artefact of undersampling with any degree of confidence. Increasing sampling areas will lead to an increased probability of encountering rare species (Gotelli and Colwell, 2001). Therefore further surveys of poorly explored areas in the North Atlantic will help clarify this issue. The uncertainty regarding endemicity is even greater for those groups that are less well studied (e.g. Clavulariidae, Nephtheidae and Anthothelidae) and thus likely under-represented in species lists worldwide due to limited taxonomic expertise. 
Table 5. Zoogeographic affinities of the coral fauna of the Azores EEZ. Values represent the percentage of faunal composition shared with each geographical region (in brackets is the percentage of species only found in that region, besides the Azores). Regions are adapted from Cairns and Chapman (2001) and Watling et al. (2011): IA-ID - western North Atlantic, Cape Hatteras to Florida Straits, Antilles, Caribbean, Gulf of Mexico, Guyana to tropical coast of Brazil; IIA - western North Atlantic, southern Greenland, East Canada from Baffin Island and Davis Strait to Cape Hatteras; IIB - boreal eastern Atlantic; IIIA - Lusitanian-Mediterranean; IIIB - seamounts south of the Azores and between Portugal and Madeira; IIIC - West Africa, Mauritania, Senegal and Gulf of Guinea; IIID- Canary Islands and Cape Verde; IO Indian Ocean; IWP - Indo-West Pacific; NEP - eastern North Pacific. Data sources used to compile species distributions are listed in Table 1.

\begin{tabular}{|c|c|c|c|c|c|c|c|c|c|c|c|c|}
\hline \multirow[t]{2}{*}{$\begin{array}{l}\text { Taxonomic } \\
\text { group }\end{array}$} & \multicolumn{2}{|c|}{$\begin{array}{l}\text { Western North } \\
\text { Atlantic }\end{array}$} & \multicolumn{5}{|c|}{ Eastern North Atlantic } & \multicolumn{3}{|c|}{ Outside NE Atlantic } & \multirow[t]{2}{*}{$\begin{array}{l}\text { Amphi- } \\
\text { Atlantic }\end{array}$} & \multirow[t]{2}{*}{$\begin{array}{l}\text { Potential } \\
\text { endemics }\end{array}$} \\
\hline & IA-ID & IIA & IIB & IIIA & IIIB & IIIC & IIID & IO & IWP & NEP & & \\
\hline Alcyonacea & $\begin{array}{l}10.37 \\
(1.22)\end{array}$ & $\begin{array}{c}4.27 \\
(0.00)\end{array}$ & $\begin{array}{c}9.76 \\
(1.22)\end{array}$ & $\begin{array}{l}33.54 \\
(9.76)\end{array}$ & $\begin{array}{c}7.93 \\
(0.61)\end{array}$ & $\begin{array}{l}14.63 \\
(0.00)\end{array}$ & $\begin{array}{l}14.02 \\
(1.22)\end{array}$ & $\begin{array}{l}3.05 \\
(0.00)\end{array}$ & $\begin{array}{c}0.61 \\
(0.00)\end{array}$ & $\begin{array}{c}1.83 \\
(0.61)\end{array}$ & 12.20 & 7.93 \\
\hline Antipatharia & 0.00 & $\begin{array}{c}1.22 \\
(0.00)\end{array}$ & $\begin{array}{c}1.83 \\
(0.00)\end{array}$ & $\begin{array}{c}6.71 \\
(0.61)\end{array}$ & $\begin{array}{c}4.27 \\
(0.61)\end{array}$ & 0.00 & $\begin{array}{c}4.27 \\
(1.22)\end{array}$ & 0.00 & $\begin{array}{c}1.22 \\
(0.00)\end{array}$ & 0.00 & 1.22 & 1.83 \\
\hline Scleractinia & $\begin{array}{l}19.51 \\
(2.44)\end{array}$ & $\begin{array}{l}10.98 \\
(0.00)\end{array}$ & $\begin{array}{c}7.93 \\
(0.00)\end{array}$ & $\begin{array}{l}29.27 \\
(0.61)\end{array}$ & $\begin{array}{l}15.85 \\
(0.61)\end{array}$ & $\begin{array}{c}9.76 \\
(0.61)\end{array}$ & $\begin{array}{l}10.98 \\
(0.00)\end{array}$ & 0.00 & 9.76 & 0.00 & 21.95 & 1.83 \\
\hline Stylasteridae & $\begin{array}{c}1.22 \\
(1.22)\end{array}$ & 0.00 & 0.00 & $\begin{array}{c}1.83 \\
(0.61)\end{array}$ & $\begin{array}{c}0.61 \\
(0.00)\end{array}$ & 0.00 & $\begin{array}{c}1.22 \\
(0.00)\end{array}$ & 0.00 & 0.00 & 0.00 & 0.00 & 2.44 \\
\hline All groups & $\begin{array}{l}31.10 \\
(4.88)\end{array}$ & $\begin{array}{l}16.46 \\
(0.00)\end{array}$ & $\begin{array}{l}19.51 \\
(1.22)\end{array}$ & $\begin{array}{c}71.34 \\
(11.59)\end{array}$ & $\begin{array}{l}28.66 \\
(1.83)\end{array}$ & $\begin{array}{l}24.39 \\
(0.61)\end{array}$ & $\begin{array}{l}30.49 \\
(2.44)\end{array}$ & $\begin{array}{l}3.05 \\
(0.00)\end{array}$ & $\begin{array}{l}11.59 \\
(0.00)\end{array}$ & $\begin{array}{c}1.83 \\
(0.61)\end{array}$ & 35.37 & 14.02 \\
\hline
\end{tabular}

The coral fauna of the Azores shows the closest affinity with the Lusitanian-Mediterranean zoogeographic region, with which it shares $71 \%$ of its species. A similar trend has been observed in shallow-water faunas including sponges (Boury-Esnault and Lopes, 1985; Moss, 1992), crustaceans (Lopes et al., 1993), molluscs (Ávila, 2000; Malaquias et al., 2009) and fishes (Briggs, 1974), as well as in deep demersal fish assemblages (Menezes et al., 2006). There are also major common components with the western North Atlantic $(33 \%)$, the Canary and Cape Verde islands $(30 \%)$ and the seamounts located south of the Azores and between mainland Portugal and Madeira (28\%). Several studies have previously reported high similarities between seamount faunas and those from the nearest continental margin (Wilson and Kaufman, 1987; McClain et al., 2009a; Rowden et al., 2010). In the northeast Atlantic, Surugiu et al. (2008) found that $73 \%$ of the polychaetes from seamounts off the Iberian and African coasts and south of the Azores were shared with the neighbouring continental margins. Ávila and Malaquias (2003) reported that a high proportion of the molluscan fauna inhabiting Ormonde Seamount has strong affinities with the nearby Portuguese continental shelf, the Mediterranean and the Macaronesian archipelagos of Madeira and the Canaries.

High dispersal ability has likely played a key role in the colonization of the isolated benthic habitats of the Azores by corals. Although lacking consistent empirical support, dispersal potential is often considered an important determinant of species range sizes (reviewed by Lester et al., 2007). Most coral species occurring in the Azores are broadly distributed, while only a few are apparently restricted to a single geographic origin. For example, less than $5 \%$ of the species are shared exclusively with the western Atlantic, and just over $2 \%$ with the Canary and Cape Verde islands. Conversely, $35 \%$ of the species have amphi-Atlantic distributions and $16 \%$ can be found in other ocean basins.

Because dispersal takes place during the larval stage for most benthic marine invertebrates, reproductive and larval development strategies may provide clues to infer dispersal ability and help to unravel the processes that shaped contemporary biogeographical patterns. The limited information available for corals distributed in the Azores suggests broadcast spawning as the most common mode of sexual reproduction. It has been reported in the scleractinians Fungiacyathus (Bathyactis) marenzelleri, M. oculata, Caryophyllia (Caryophyllia) ambrosia, L. pertusa, Premocyathus cornuformis, S. variabilis, F. alabastrum, F. angulare and Enallopsammia rostrata (see Waller, 2005, and references therein), as well as the alcyonacean A. arbuscula (Beazley and Kenchington, 2012). This is likely the prevailing reproductive mode also in antipatharians in general (Wagner et al., 2012). For most of the above species, a lecithotrophic larval stage was inferred from oocyte size and planulae observations. Development times (and therefore dispersal distances) are reportedly low for many shallow water lecithotrophic larvae (Shanks, 2009). In the deep sea, however, the effects of low temperature (O'Connor et al., 2007; Bradbury et al., 2008) and pressure (Somero, 1998) on larval metabolism may extend planktonic larval duration, leading to an increase of dispersal potential. In addition, some lecithotrophic coral larvae have the ability to delay metamorphosis for months, thus greatly prolonging the dispersive phase (Cordes et al., 2001; Sun et al., 2010). 
A correspondence between low dispersal potential and narrow geographical range is apparent among the Stylasteridae. This family, generally reported as having brooded larvae with very short planktonic periods (Brooke and Stone, 2007), shows the highest rate of apparent endemicity (four out of nine species) and limited distributions among the four major groups examined in this study. However, the same relationship was not observed in another brooding species, $A n$ thomastus grandiflorus (Mercier and Hamel, 2011), which has a wide geographical distribution. It seems therefore clear that although larval type may largely determine dispersal potential, a number of other factors such as dispersal barriers, currents and larval behaviour may come into play to modulate realized dispersal and limit range size (McClain and Hardy, 2010). Finally, a hypothetical role of asexual reproduction (budding, fission, parthenogenesis, etc.), especially for direct developing species, cannot be ruled out, even though its effectiveness has not been assessed in deep-sea species.

\subsection{Spatial structure}

Our multivariate analysis revealed significant geographical structure in assemblage composition across the study area. Possible explanations for this result are unclear owing to the fact that the observed pattern of differentiation among longitudinal sections was not supported by the presence of consistently discriminating species. It should be noted that, because only presence/absence data were used, hypothetical geographical patterns arising from changes in abundance or species dominance, not composition, remain undetected.

The spatial structure in species composition found in our data may reflect variability among features, as suggested by data points in the nMDS ordination being loosely clustered. On the other hand, the placement of the study area along a $600 \mathrm{~km} \mathrm{NW-SE} \mathrm{strip} \mathrm{intersected} \mathrm{by} \mathrm{the} \mathrm{MAR} \mathrm{(which} \mathrm{sepa-}$ rates western from central and eastern sections) may help to explain the observed geographical differences if (1) a higher proportion of western species or a lower proportion of eastern species was found on the western section, which would suggest that the MAR could be an effective biogeographical barrier, or if (2) a higher proportion of northern species or a lower proportion of southern species was found in the western group compared to the central and especially the eastern group, which would be indicative of a latitudinal effect. We classified each species in terms of latitudinal range (endemic, northern, southern, broadly distributed) and zoogeographic affinity (endemic, Great Meteor Seamount, eastern, western, amphi-Atlantic, cosmopolitan) and tested if their relative proportions differed among longitudinal sections using separate chi-square tests. We found no significant differences, both for latitudinal range $\left(\chi^{2}=2.048, P=0.915\right.$, d.f. $=6)$ and zoogeographic affinity $\left(\chi^{2}=6.752, P=0.749\right.$, d.f. $=10)$.
The above results suggest that the MAR does not constitute a biogeographic barrier for corals in the area. This is in line with previous surveys of deep-sea fauna at the MAR, which did not report any marked cross-ridge differences in species composition for bathypelagic (Sutton et al., 2008) and demersal fish (Bergstad et al., 2008). However, we cannot rule out the possibility that the MAR may pose an obstacle to east-west dispersal, especially in lower bathyal (Gebruk et al., 2010) and abyssal fauna (McClain et al., 2009b; Etter et al., 2011). The scarcity of records for these depths in our data set does not allow investigating this hypothesis.

A latitudinal gradient in species composition was not observed at the spatial scale of this study. The northernmost and southernmost sampling locations, differing roughly by 2.5 degrees of latitude, showed similar proportions of northern vs. southern species. Such differences are likely to arise at wider latitudinal ranges. For example, a distinct latitudinal variation in the composition of demersal fish assemblages (e.g. Hareide and Garnes, 2001; Bergstad et al., 2008; Bergstad et al., 2012) and bathyal invertebrate fauna (Gebruk et al., 2010) was detected between different sections of the northern MAR, but not in demersal fishes within the Azores archipelago (Menezes et al., 2006). Recent surveys on the MAR north of the Azores revealed that most of the alcyonaceans, antipatharians and scleractinians found are shared with the Azores (Molodtsova et al., 2008; Mortensen et al., 2008), but some of the few exceptions were species with northern or antitropical ranges, such as Primnoa resedaeformis, Paragorgia arborea and cf. Stauropathes arctica. Latitudinal gradients in species distributions along the northern MAR and their underlying causes can only be fully understood with more consistent sampling beyond the regional scale. Nevertheless, a faunal transition may occur (in particular above mid bathyal depths) in the vicinity of the northern boundary of the Azores EEZ, reflecting meridional temperature gradients established by the convergence of the major current flows in the region (Bashmashnikov et al., 2004).

The strongest changes in species composition occurred with depth. Depth-related faunal zonation (e.g. Copley et al., 1996; Howell et al., 2002; Menezes et al., 2006; Yeh and Drazen, 2009; Bergstad et al., 2012) and even vertical stratification within the same species (Zardus et al., 2006; Miller et al., 2011) have been commonly reported in the deep sea. The rate of faunal change assessed in this study was more pronounced from shallow $(100-600 \mathrm{~m})$ to intermediate $(600-1000 \mathrm{~m})$ depth intervals, possibly reflecting not only sharper environmental gradients but also greater topographic complexity and substrate heterogeneity usually found at upper bathyal depths (Buhl-Mortensen et al., 2010). The fact that soft substrates become predominant at greater depths and restrict the establishment of corals requiring hard substrates to settle could also explain the sharp decrease in species diversity below $2200 \mathrm{~m}$, although this observation should be considered cautiously due to the relatively limited sampling at those depths. 
We did not identify clear faunal boundaries, but rather a mix of steno- and eurybathic species with partially overlapping distributions. As expected, this pattern suggests that a combination of factors are involved in the establishment of depth ranges, such as food availability, temperature, pressure and stratification of water masses, as well as biological interactions and processes such as competition, predation and dispersal (reviewed by Carney, 2005). Moreover, our analysis did not account for bottom type, which means that there may be also a confounding effect of this variable, known to greatly influence coral distribution (e.g. Baker et al., 2012), on the perceived vertical gradient of the coral fauna.

Two other depth-related trends of faunal change emerged from our data. First, the proportion of amphi-Atlantic and cosmopolitan species increased from $19 \%$ and $16 \%$, respectively, at $100-600 \mathrm{~m}$ to $26 \%$ and $23 \%$ at the $1000-1500 \mathrm{~m}$ depth interval. This observation agrees with the contention that species range sizes tend to increase with depth, possibly as a result of more constant environmental conditions (Etter and Rex, 1990; Allen and Sanders, 1996). Second, with increasing depth there was also a growing proportion of highlatitude species ( $7 \%$ at $100-600 \mathrm{~m}$ to $21 \%$ at $1000-1500 \mathrm{~m}$ ) and a corresponding decline of low-latitude species $(69 \%$ at $100-600 \mathrm{~m}$ to $53 \%$ at $1000-1500 \mathrm{~m}$ ). This pattern is consistent with the depth of the permanent thermocline in the NE Atlantic (600-1000 m) and the predominance beneath its lower boundary of deep-water masses formed at high latitudes (i.e. the Subarctic Intermediate Water and the Labrador Sea Water).

\subsection{Conservation issues}

Coral assemblages found on seamounts and island slopes showed high taxonomic richness at both species and family levels, indicating that benthic habitats of the Azores harbour numerous species currently recognized as key indicators of vulnerable marine ecosystems (VMEs) (OSPAR, 2008; FAO, 2009). Moreover, species diversity appears to be higher in the Azores than in other Macaronesian archipelagos. For example, 89 species have been reported in the Canary Islands, comprising 36 alcyonaceans, 42 scleractinians, 8 antipatharians and 3 stylasterids (Zibrowius and Cairns, 1992; Brito and Ocaña, 2004). The United Nations General Assembly (UNGA 61/105 and 64/72) led to a number of resolutions aiming to implement a precautionary approach to sustainably manage fishing resources yet protecting VMEs from destructive fishing practices (FAO, 2009; Auster et al., 2011). At a regional scale, spatial conservation measures implemented recently that may contribute to the protection of coral habitats include the following: (1) the temporary closure of Condor de Terra Seamount to bottom fishing activities, which is currently a multidisciplinary scientific observatory (Morato et al., 2010); and (2) the inclusion of a set of marine protected areas in the recently designated and legally binding Azores Marine Park (DLR, 2011), which incorporates not only areas on the EEZ such as the Menez Gwen and Lucky Strike hydrothermal fields, and the Sedlo and Dom João de Castro seamounts, but also Rainbow, Altair, Antialtair and MAR north of the Azores that are outside the EEZ but on the Portuguese continental shelf. Also, bottom trawling and deep-sea netting are prohibited in the region as a response to the global call for the conservation of benthic habitats from bottom fisheries (Council Regulation (EC) No. 1568/2005; Probert et al., 2007). Nonetheless, a number of corals are still vulnerable to the longline fishing (Sampaio et al., 2012; this study), although the true impact of this gear has not yet been assessed.

\section{Conclusions}

This study meets the global need for comprehensive accounts of the taxonomic diversity and distribution of coldwater corals, which can be used as relevant input for predictive habitat modelling, assessment of habitat-fisheries interactions and conservation policies. Overall, our analysis revealed high species diversity and significant structure in species composition, both geographically and with depth. Understanding the processes by which such patterns are established and maintained will require not only a detailed characterization of the physical environment in which species occur but also the investigation of biotic factors that have so far been largely overlooked in deep-sea studies.

More detailed spatial patterns may emerge as species lists are populated with new records, especially from deeper and less explored habitats $(>1500 \mathrm{~m})$. However, standardized collection methods will be necessary to significantly improve the statistical power required to detect spatial changes in community structure by enabling the use of abundance data.

One of the key aspects that must be considered in biogeographical studies of corals is the generally insufficient expertise in morphological taxonomy. This shortcoming may lead to inaccurate taxonomic inventories or to lists with low taxonomic resolution that will compromise the validity of assessed biogeographical patterns. Despite its growing usefulness, molecular systematics still requires integration with classic morphological taxonomy to achieve conclusive species identification. Therefore, a greater investment in taxonomic training will be essential to tackle the challenge of characterizing deep-sea faunas in a time of increasing, and more sophisticated, scientific exploration.

\section{Supplementary material related to this article is available online at: http://www.biogeosciences.net/10/ 4009/2013/bg-10-4009-2013-supplement.pdf.}




\section{Appendix A}

Table A1. List of species of Alcyonacea, Antipatharia, Scleractinia and Stylasteridae identified in the Azores EEZ according to major oceanographic campaigns, other sources and IMAR-DOP/UAc records. Records from the CANCAP-V available online at the collection database of the Smithsonian National Museum of Natural History are indicated with an asterisk. See Table 1 for data source details. Signs in boldface indicate first species records.

\begin{tabular}{|c|c|c|c|c|c|c|c|c|c|}
\hline Taxa & Josephine & Challenger & Talisman & PAM & Biaçores & Bartlett & CANCAP-V & Other & $\begin{array}{l}\text { IMAR-DOP } \\
\text { records }\end{array}$ \\
\hline \multicolumn{10}{|l|}{ Alcyonacea } \\
\hline \multicolumn{10}{|l|}{ "True soft corals" } \\
\hline \multicolumn{10}{|l|}{ Cornulariidae } \\
\hline Cornularia cornucopiae (Pallas, 1766) & & & & & + & & & & \\
\hline \multicolumn{10}{|l|}{ Clavulariidae } \\
\hline Azoriella bayeri (López-González and Gili, 2001) & & & & & & & & + & \\
\hline Bathytelesto rigida (Wright and Studer, 1889) & & + & & & & & & & \\
\hline Clavularia arctica (Sars, 1860) & & & & + & & & & & \\
\hline Clavularia armata (Thomson, 1927) & & & & + & & & + & & \\
\hline Clavularia elongata (Wright and Studer, 1889) & & + & & & + & & & & \\
\hline Clavularia marioni (von Koch, 1891) & & & & + & + & & & & \\
\hline Clavularia tenuis (Tixier-Durivault and d'Hondt, 1975) & & & & & + & & & & \\
\hline Clavularia tubaria (Wright and Studer, 1889) & & & & + & & & & & \\
\hline Rolandia coralloides (Lacaze-Duthiers, 1900) & & & & + & & & & & \\
\hline Sarcodictyon catenatum (Forbes, 1847) & & & & & + & & & & + \\
\hline Sarcodictyon charcoti (Tixier-Durivault and d'Hondt, 1975) ${ }^{\mathrm{a}}$ & & & & & + & & & & \\
\hline Scleranthelia rugosa (Pourtalès, 1867) & + & & & & & & & & \\
\hline Scyphopodium ingolfi (Madsen, 1944) & & & & & & & & + & \\
\hline Telestula batoni (Weinberg, 1990) & & & & + & & & & & \\
\hline Telestula humilis (Thomson, 1927) & & & & + & & & & & \\
\hline Telestula kuekenthali (Weinberg, 1990) & & & & + & & & & & \\
\hline \multicolumn{10}{|l|}{ Organidae } \\
\hline Schizophytum echinatum (Studer, 1891)*b & & & & + & + & & + & & + \\
\hline \multicolumn{10}{|l|}{ Paralcyoniidae } \\
\hline Paralcyonium spinulosum (Delle Chiaje, 1822) & & & + & & & & & & \\
\hline \multicolumn{10}{|l|}{ Alcyoniidae } \\
\hline Alcyonium bocagei (Saville Kent, 1870) & & & & & + & & & & + \\
\hline Alcyonium grandiflorum (Tixier-Durivault and d'Hondt, 1975) & & & & & + & & & & \\
\hline Alcyonium maristenebrosi (Stiasny, 1937) & & & & & & & & & + \\
\hline Alcyonium palmatum (Pallas, 1766) & & & & + & & & & & \\
\hline Alcyonium profundum (Stokvis and van Ofwegen, 2006) & & & & & & & & + & \\
\hline Alcyonium rubrum (Stokvis and van Ofwegen, 2006) & & & & & & & & & + \\
\hline Anthomastus agaricus (Studer, 1891) & & & & + & + & & & & + \\
\hline Anthomastus canariensis (Wright and Studer, 1889) & & & & & + & & & & \\
\hline Anthomastus grandiflorus (Verrill, 1878) & & & & & + & & + & & \\
\hline Bellonella bocagei (Saville Kent, 1870) & & + & & + & + & & & & \\
\hline Bellonella tenuis (Tixier-Durivault and d'Hondt, 1975) & & & & & + & & & & \\
\hline Bellonella variabilis (Studer, 1891) & & & & + & + & & & & \\
\hline $\begin{array}{l}\text { Pseudoanthomastus inusitatus } \\
\text { (Tixier-Durivault and d'Hondt, 1975) }\end{array}$ & & & & & + & & & & + \\
\hline \multicolumn{10}{|l|}{ Nephtheidae } \\
\hline Gersemia clavata (Danielssen, 1887) & & & & + & & & & + & \\
\hline Scleronephthya macrospina (Thomson, 1927) & & & & + & & & & & \\
\hline \multicolumn{10}{|l|}{ Gorgonians "Scleraxonia" } \\
\hline \multicolumn{10}{|l|}{ Anthothelidae } \\
\hline Anthothela grandiflora (M. Sars, 1856) & & & & + & & & + & + & \\
\hline Titanideum obscurum (Thomson, 1927) & & & & + & & & & & \\
\hline \multicolumn{10}{|l|}{ Paragorgiidae } \\
\hline Paragorgia johnsoni (Gray, 1862) & & & & & & & & & + \\
\hline \multicolumn{10}{|l|}{ Coralliidae } \\
\hline Corallium johnsoni (Gray, 1860) & & & & + & & & & + & + \\
\hline Corallium niobe (Bayer, 1964) & & & & & & & & + & \\
\hline \multicolumn{10}{|l|}{ Gorgonians "Holaxonia" } \\
\hline \multicolumn{10}{|l|}{ Acanthogorgiidae } \\
\hline Acanthogorgia armata (Verrill, 1878) & & & & + & + & + & + & + & + \\
\hline Acanthogorgia aspera (Pourtalès, 1867) & & & & & + & & & & \\
\hline Acanthogorgia hirsuta (Gray, 1857) & & & & + & + & & + & + & + \\
\hline Acanthogorgia muricata (Verrill, 1883) & & & & & + & & & & \\
\hline Acanthogorgia pico (Grasshoff, 1973) & & & & + & & & & & \\
\hline
\end{tabular}


Table A1. Continued.

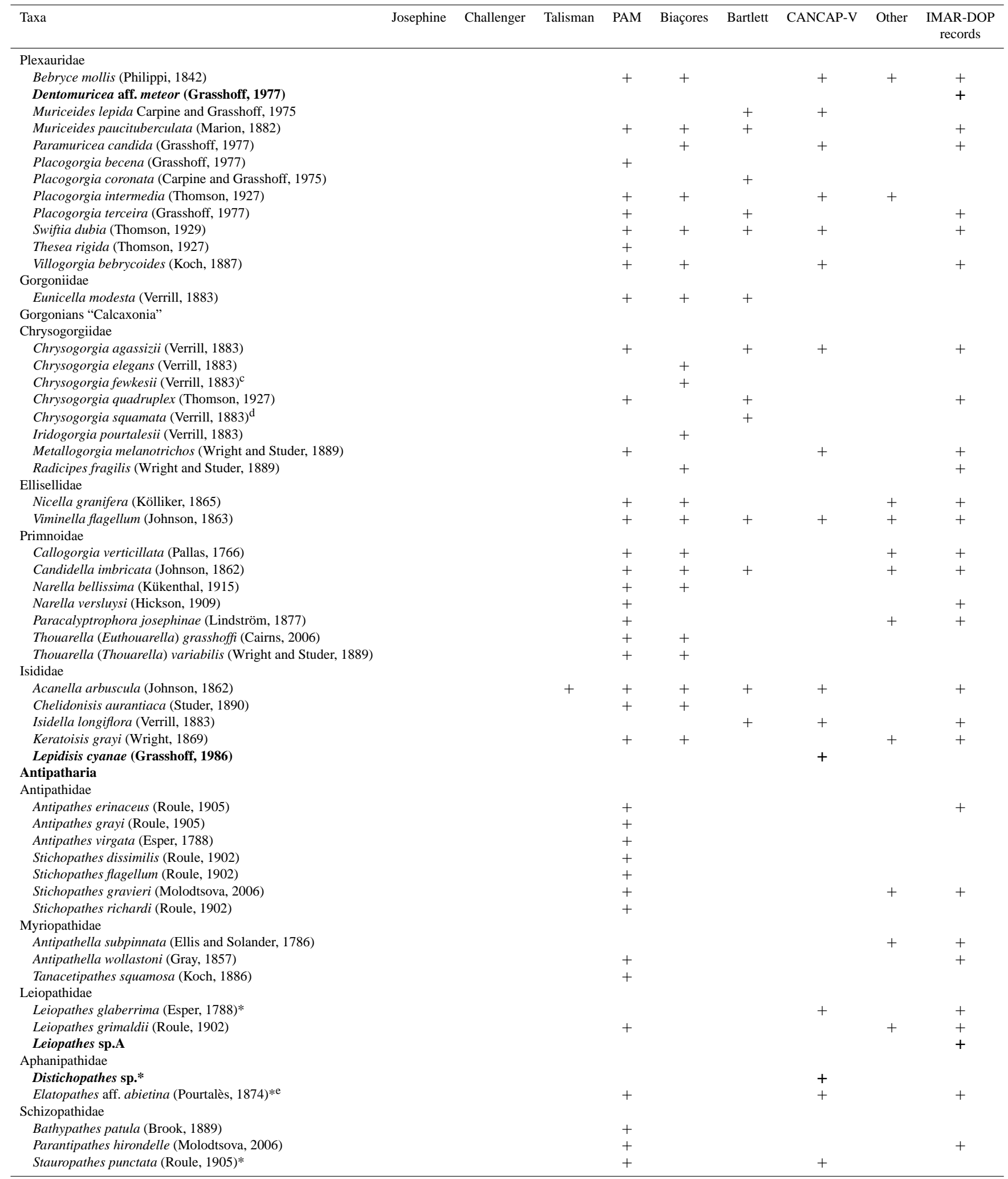


Table A1. Continued.

\begin{tabular}{|c|c|c|c|c|c|c|c|c|c|}
\hline Taxa & Josephine & Challenger & Talisman & PAM & Biaçores & Bartlett & CANCAP-V & Other & $\begin{array}{l}\text { IMAR-DOP } \\
\text { records }\end{array}$ \\
\hline \multicolumn{10}{|l|}{ Scleractinia } \\
\hline \multicolumn{10}{|l|}{ Pocilloporidae } \\
\hline Madracis pharensis (Heller, 1868) & & & & & & & & + & + \\
\hline Madracis profunda (Zibrowius, 1980) & & & & & + & & & & \\
\hline \multicolumn{10}{|l|}{ Fungiacyathidae } \\
\hline Fungiacyathus (Bathyactis) crispus (Pourtalès, 1871) & + & & & & + & & & & \\
\hline Fungiacyathus (Bathyactis) marenzelleri (Vaughan, 1906) & & & & + & + & + & & & \\
\hline Fungiacyathus (Bathyactis) symmetricus (Pourtalès, 1871) & & + & & & & & & & \\
\hline Fungiacyathus (Fungiacyathus) fragilis (G.O. Sars, 1872) & & & & + & + & & & & \\
\hline \multicolumn{10}{|l|}{ Oculinidae } \\
\hline Madrepora oculata (Linnaeus, 1758) & & & + & + & + & + & & + & + \\
\hline \multicolumn{10}{|l|}{ Caryophylliidae } \\
\hline Anomocora fecunda (Pourtalès, 1871) & & & & & + & & & & + \\
\hline Aulocyathus atlanticus (Zibrowius, 1980) & & & & + & + & & & & \\
\hline Caryophyllia (Caryophyllia) abyssorum (Duncan, 1873) & & & & + & + & & & & + \\
\hline Caryophyllia (Caryophyllia) alberti (Zibrowius, 1980) & & + & & + & + & + & + & & + \\
\hline Caryophyllia (Caryophyllia) ambrosia (Alcock, 1898) & & + & + & + & + & & + & + & \\
\hline Caryophyllia (Caryophyllia) atlantica (Duncan, 1873) & & & & + & & + & & & \\
\hline Caryophyllia (Caryophyllia) calveri (Duncan, 1873) & & & & + & + & & & & + \\
\hline Caryophyllia (Caryophyllia) cyathus (Ellis and Solander, 1786) & & & & + & + & + & + & + & + \\
\hline Caryophyllia (Caryophyllia) foresti (Zibrowius, 1980) & & & & + & + & & & & + \\
\hline Caryophyllia (Caryophyllia) inornata (Duncan, 1878) & & & & & + & & & + & + \\
\hline Caryophyllia (Caryophyllia) sarsiae (Zibrowius, 1974) & & & & + & + & + & & & \\
\hline Caryophyllia (Caryophyllia) smithii (Stokes and Broderip, 1828) & + & & & + & + & & & + & + \\
\hline Coenocyathus cylindricus (Milne Edwards and Haime, 1848) & & & & & & & & & + \\
\hline Concentrotheca laevigata (Pourtalès, 1871) & & & & & + & & & & \\
\hline Dasmosmilia lymani (Pourtalès, 1871) & & & & & + & & & & \\
\hline Dasmosmilia variegata (PourtaIes, 1871) & & & & + & + & & & & \\
\hline Deltocyathus eccentricus (Cairns, 1979) & & & & + & + & + & & & \\
\hline Deltocyathus italicus (Michelotti, 1838) & & + & & + & + & & & & \\
\hline Deltocyathus moseleyi (Cairns, 1979) & + & & & + & + & + & & & \\
\hline Desmophyllum dianthus (Esper, 1794) & & & & + & + & + & & + & + \\
\hline Lophelia pertusa (Linnaeus, 1758) & & & + & + & + & & & + & + \\
\hline Paracyathus pulchellus (Philippi, 1842) & + & + & & + & + & & & + & + \\
\hline Pourtalosmilia anthophyllites (Ellis and Solander, 1786) & & & & & + & & & & \\
\hline Premocyathus cornuformis (Pourtalès, 1868) & & & & + & + & & + & & + \\
\hline Solenosmilia variabilis (Duncan, 1873) & & & & + & + & & + & + & + \\
\hline $\begin{array}{l}\text { Stephanocyathus (Odontocyathus) nobilis } \\
\text { (Moseley in Thompson, 1873) }\end{array}$ & & + & & + & + & + & + & & \\
\hline Stephanocyathus (Stephanocyathus) crassus (Jourdan, 1895) & & & & + & + & + & & & \\
\hline Stephanocyathus (Stephanocyathus) diadema (Moseley, 1876) & & + & & & & & & & \\
\hline Stephanocyathus (Stephanocyathus) moseleyanus (Sclater, 1886) & & & & + & + & + & + & & \\
\hline Tethocyathus variabilis (Cairns, 1979) & & & & & + & & & & \\
\hline Trochocyathus (Trochocyathus) spinosocostatus (Zibrowius, 1980) & & & & & + & & & & \\
\hline Vaughanella concinna (Gravier, 1915) & & & & + & + & + & & & \\
\hline \multicolumn{10}{|l|}{ Turbinoliidae } \\
\hline Deltocyathoides stimpsonii (Pourtalès, 1871) & + & & & + & + & & & & \\
\hline Peponocyathus folliculus (Pourtalès, 1868) & + & & & + & + & & & & \\
\hline $\begin{array}{l}\text { Sphenotrochus (Sphenotrochus) andrewianus } \\
\text { (Milne Edwards and Haime, 1848) }\end{array}$ & + & & & & + & & & & \\
\hline \multicolumn{10}{|l|}{ Flabellidae } \\
\hline Flabellum (Flabellum) chunii (Marenzeller, 1904) & & & & + & + & + & & & + \\
\hline Flabellum (Ulocyathus) alabastrum (Moseley in Thomson, 1873) & & + & + & + & + & + & & & \\
\hline Flabellum (Ulocyathus) angulare (Moseley, 1876) & & & & & + & & & & \\
\hline Flabellum (Ulocyathus) macandrewi (Gray, 1849) & + & & & & + & & & & \\
\hline Javania cailleti (Duchassaing and Michelotti, 1864) & & & & + & + & & & & + \\
\hline Javania pseudoalabastra (Zibrowius, 1974) & & & & + & + & & & & \\
\hline \multicolumn{10}{|l|}{ Guyniidae } \\
\hline Guynia annulata (Duncan, 1872) & & & & & + & & & & \\
\hline \multicolumn{10}{|l|}{ Stenocyathidae } \\
\hline Stenocyathus vermiformis (Pourtalès, 1868) & + & & + & + & + & & & & + \\
\hline Schizocyathidae & & & & & & & & & \\
\hline Schizocyathus fissilis (Pourtalès, 1874) & & & & + & + & & & & \\
\hline Dendrophylliidae & & & & & & & & & \\
\hline Balanophyllia (Balanophyllia) cellulosa (Duncan, 1873) & & & & & + & & & & \\
\hline Dendrophyllia alternata (Pourtalès, 1880) & & & & & + & & & & + \\
\hline Dendrophyllia cornigera $\left(\right.$ Lamarck, 1816) ${ }^{\mathrm{f}}$ & & & & & + & & & + & + \\
\hline Dendrophyllia ramea (Linneus, 1758) & & & & & & & & & + \\
\hline Enallopsammia pusilla (Alcock, 1902) & & & & & + & & & & \\
\hline Enallopsammia rostrata (Pourtalès, 1878) & & & + & + & + & & & + & + \\
\hline Leptopsammia formosa (Gravier, 1915) ${ }^{\mathrm{g}}$ & & & + & + & + & & + & & \\
\hline
\end{tabular}


Table A1. Continued.

\begin{tabular}{|c|c|c|c|c|c|c|c|c|c|}
\hline Taxa & Josephine & Challenger & Talisman & PAM & Biaçores & Bartlett & CANCAP-V & Other & $\begin{array}{l}\text { IMAR-DOP } \\
\text { records }\end{array}$ \\
\hline \multicolumn{10}{|l|}{ Athecatae } \\
\hline \multicolumn{10}{|l|}{ Stylasteridae } \\
\hline Crypthelia affinis (Moseley, 1879) & & & & + & + & & & & + \\
\hline Crypthelia medioatlantica (Zibrowius and Cairns, 1992) & & & & + & & + & & & \\
\hline Crypthelia tenuiseptata (Cairns, 1986) & & & + & + & + & & & & + \\
\hline Crypthelia vascomarquesi (Zibrowius and Cairns, 1992) & & & + & + & + & & & & \\
\hline Errina atlantica (Hickson, 1912) & & & + & & + & & & + & + \\
\hline Errina dabneyi (Pourtalès, 1871) & & & + & + & + & + & & + & + \\
\hline Lepidopora eburnea (Calvet, 1903) & & & + & + & + & + & & & \\
\hline Pliobothrus symmetricus (Pourtalès, 1868) & & & + & + & + & & & + & + \\
\hline Stenohelia sp.A & & & & & + & & & & \\
\hline
\end{tabular}

a This species is currently under taxonomic review and will be assigned to a different genus (O. Ocaña, personal communication, 2012).

b The taxonomic classification of Schizophytum echinatum requires revision.

c Even though Carpine and Grasshoff (1985) synonymized Chrysogorgia fewkesii from PAM campaigns with the species Chrysogorgia quadruplex, Cairns (2001) did not consider as valid the few records of $C$. fewkesii reported from the eastern Atlantic (PAM campaigns - Thomson, 1927; Biaçores - Tixier-Durivault and d'Hondt, 1975) given that they were based

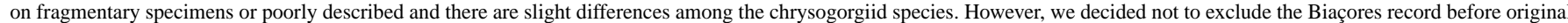
material could be examined.

$\mathrm{d}$ The presence of Chrysogorgia squamata in the Azores is also doubtful (based on a single record); further examination of the original material is still required.

e Specimens from two PAM stations are originally described as Tanacetipathes squamosa, but after the examination of the material at the Oceanographic Museum of Monaco we do believe that it is a misidentification (V. de Matos, personal communication, 2009).

${ }^{\mathrm{f}}$ Some of this material is still under revision given that we have found colonies showing different septa disposition when compared with the original description of Dendrophyllia cornigera.

$\mathrm{g}$ Squires (1959) reports this species to the Great Meteor and Atlantis seamounts, but Zibrowius did not examine these specimens (Zibrowius, 1980), and questioned the validity of those records. We followed his view and therefore considered Leptopsammia formosa as a putative endemic to the Azores.

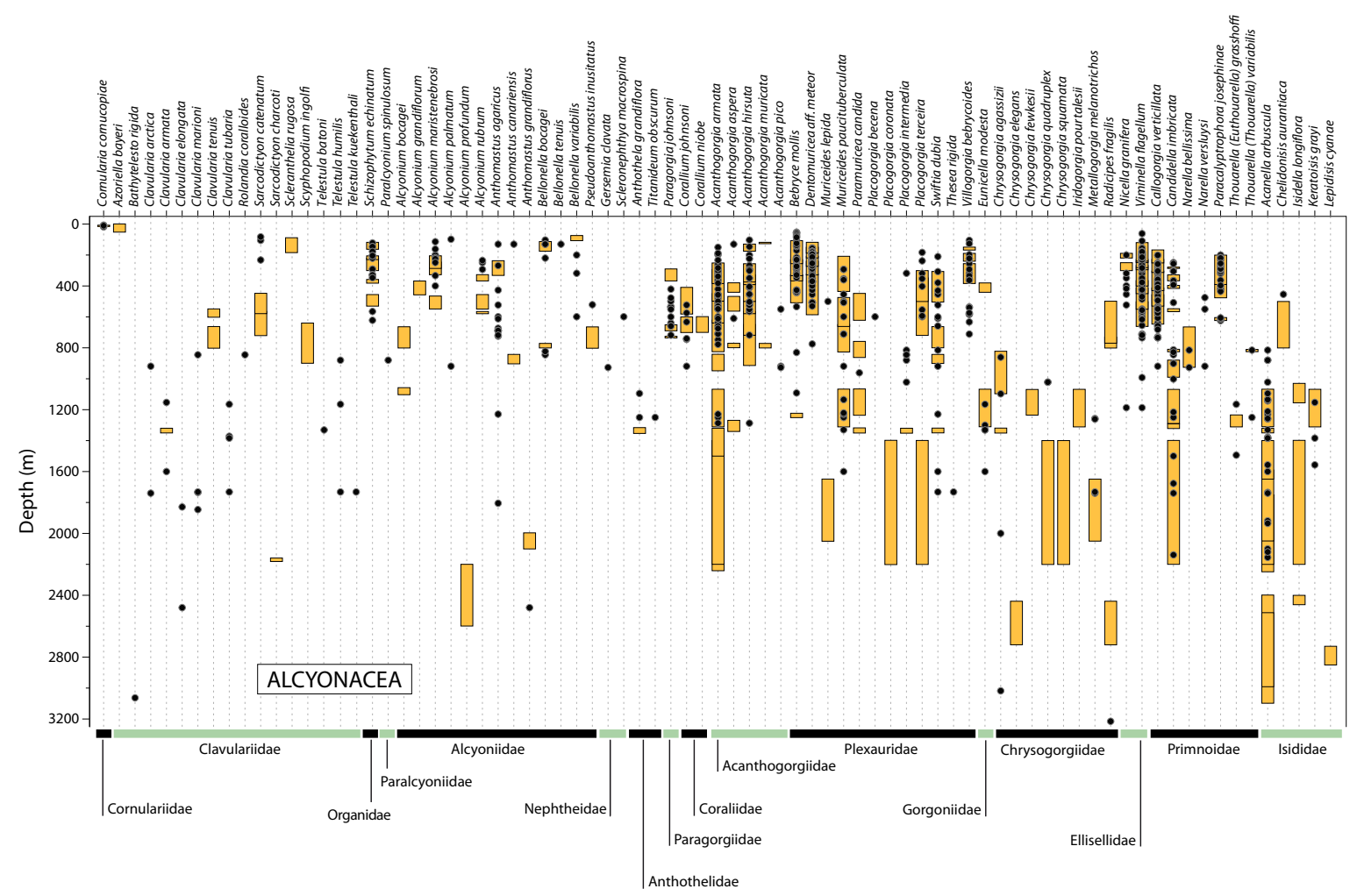

Fig. A1. Species bathymetric ranges. The stylasterid Stenohelia sp.A is not represented given that there is no bathymetric information for this record. 

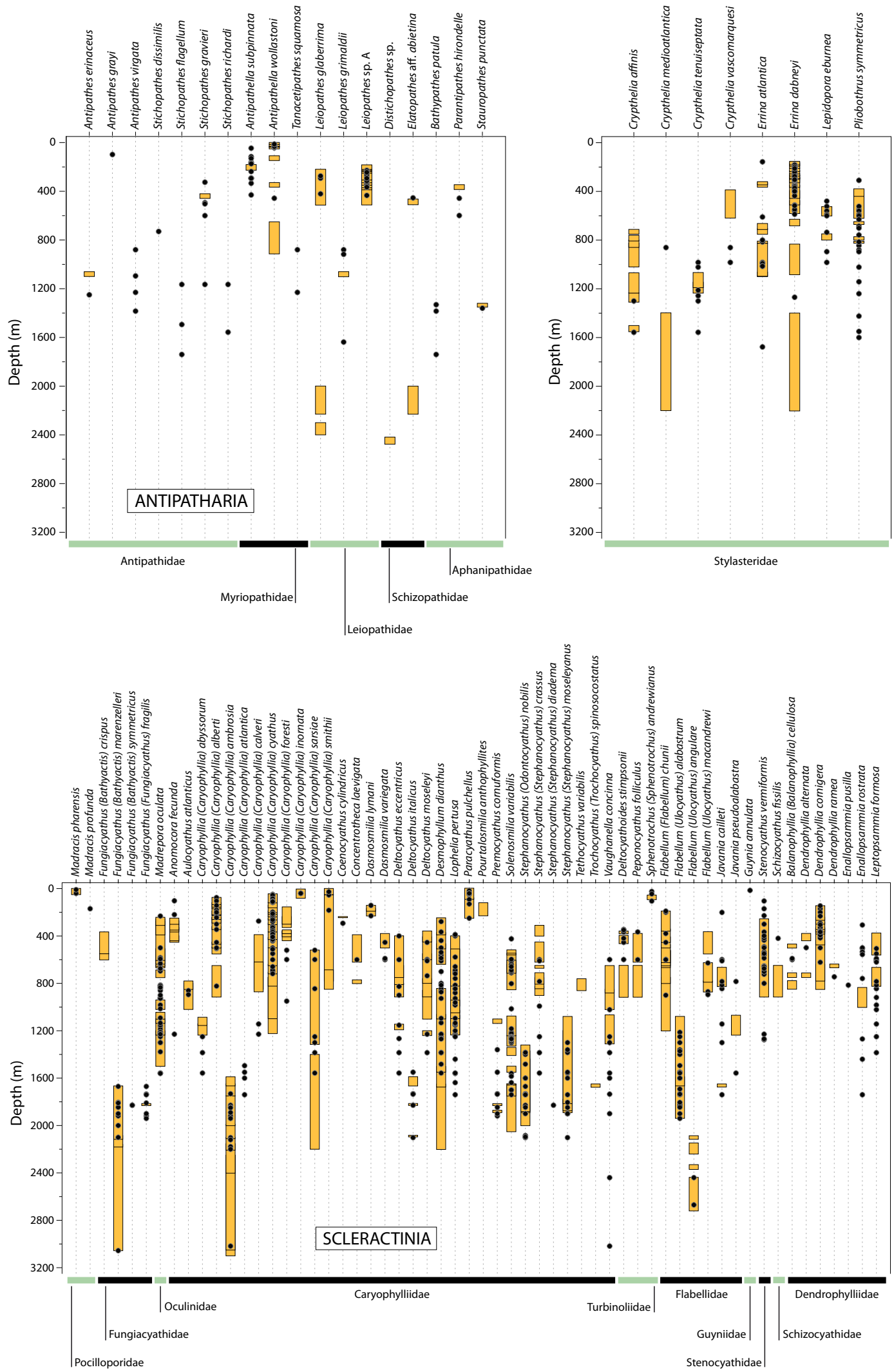

Fig. A1. Continued. 
Table A2. Breakdown of average dissimilarity between groups tested into contributions from each species after SIMPER analysis. Species are ordered in decreasing contribution (cut-off cumulative value is 30\%). Depth intervals: shallow (100-600 m), intermediate (600-1000 m) and deep (1000-1500 m). Asterisks indicate species with high discriminating power.

\begin{tabular}{|c|c|c|c|c|}
\hline \multicolumn{5}{|c|}{ Longitudinal section } \\
\hline Western vs. Central & $\begin{array}{l}\text { Av. Abund. } \\
\text { Western }\end{array}$ & $\begin{array}{l}\text { Av. Abund. } \\
\text { Central }\end{array}$ & Diss/SD & $\begin{array}{c}\text { Contrib. } \\
(\%)\end{array}$ \\
\hline Madrepora oculata & 0.23 & 0.59 & 0.69 & 4.86 \\
\hline Desmophyllum dianthus & 0.23 & 0.48 & 0.69 & 3.76 \\
\hline Stenocyathus vermiformis & 0.46 & 0.19 & 0.62 & 3.18 \\
\hline Pliobothrus symmetricus & 0.08 & 0.22 & 0.42 & 2.68 \\
\hline Lophelia pertusa & 0.31 & 0.37 & 0.52 & 2.59 \\
\hline Solenosmilia variabilis & 0.31 & 0.22 & 0.59 & 2.49 \\
\hline Candidella imbricata & 0.15 & 0.33 & 0.58 & 2.49 \\
\hline Acanthogorgia armata & 0.31 & 0.37 & 0.72 & 2.29 \\
\hline Muriceides paucituberculata & 0.46 & 0.26 & 0.79 & 2.09 \\
\hline Errina dabneyi & 0.15 & 0.41 & 0.64 & 2.04 \\
\hline Swiftia dubia & 0.23 & 0.22 & 0.78 & 2.00 \\
\hline Western vs. Eastern & $\begin{array}{l}\text { Av. Abund. } \\
\text { Western }\end{array}$ & $\begin{array}{c}\text { Av. Abund. } \\
\text { Eastern }\end{array}$ & Diss/SD & $\begin{array}{c}\text { Contrib. } \\
(\%)\end{array}$ \\
\hline Pliobothrus symmetricus & 0.08 & 0.50 & 0.59 & 3.99 \\
\hline Leptopsammia formosa & 0.00 & 0.67 & 1.25 & 3.09 \\
\hline Madrepora oculata & 0.23 & 0.42 & 0.52 & 2.97 \\
\hline Muriceides paucituberculata & 0.46 & 0.42 & 0.82 & 2.65 \\
\hline Lophelia pertusa & 0.31 & 0.33 & 0.85 & 2.21 \\
\hline Acanella arbuscula & 0.00 & 0.33 & 0.39 & 2.17 \\
\hline Deltocyathus moseleyi & 0.15 & 0.42 & 0.81 & 2.15 \\
\hline Stenocyathus vermiformis & 0.46 & 0.17 & 0.79 & 2.11 \\
\hline Errina atlantica & 0.08 & 0.42 & 0.64 & 2.04 \\
\hline Flabellum alabastrum & 0.15 & 0.08 & 0.29 & 2.01 \\
\hline Acanthogorgia armata & 0.31 & 0.33 & 0.67 & 1.96 \\
\hline Eunicella modesta & 0.08 & 0.25 & 0.35 & 1.93 \\
\hline Anthomastus agaricus & 0.15 & 0.33 & 0.78 & 1.84 \\
\hline Central vs. Eastern & $\begin{array}{l}\text { Av. Abund. } \\
\text { Central }\end{array}$ & $\begin{array}{l}\text { Av. Abund. } \\
\text { Eastern }\end{array}$ & Diss/SD & $\begin{array}{c}\text { Contrib. } \\
(\%)\end{array}$ \\
\hline Madrepora oculata & 0.59 & 0.42 & 0.54 & 3.85 \\
\hline Desmophyllum dianthus & 0.48 & 0.33 & 0.57 & 3.63 \\
\hline Acanella arbuscula & 0.15 & 0.33 & 0.39 & 2.62 \\
\hline Swiftia dubia & 0.22 & 0.33 & 0.89 & 2.59 \\
\hline Caryophyllia sarsiae & 0.11 & 0.17 & 0.30 & 2.57 \\
\hline Muriceides paucituberculata & 0.26 & 0.42 & 0.75 & 2.52 \\
\hline Leptopsammia formosa & 0.19 & 0.67 & 0.98 & 2.40 \\
\hline Stephanocyathus moseleyanus & 0.15 & 0.08 & 0.28 & 2.34 \\
\hline Errina atlantica & 0.19 & 0.42 & 0.68 & 2.30 \\
\hline Lophelia pertusa & 0.37 & 0.33 & 0.78 & 2.30 \\
\hline Candidella imbricata & 0.33 & 0.17 & 0.48 & 2.22 \\
\hline Solenosmilia variabilis & 0.22 & 0.17 & 0.47 & 1.90 \\
\hline
\end{tabular}


Table A2. Continued.

\begin{tabular}{|c|c|c|c|c|}
\hline \multicolumn{5}{|c|}{ Depth interval } \\
\hline Shallow vs. Intermediate & $\begin{array}{l}\text { Av. Abund. } \\
\text { Shallow }\end{array}$ & $\begin{array}{l}\text { Av. Abund. } \\
\text { Intermediate }\end{array}$ & Diss/SD & $\begin{array}{c}\text { Contrib. } \\
(\%)\end{array}$ \\
\hline Caryophyllia cyathus* & 0.78 & 0.11 & 1.41 & 3.47 \\
\hline Viminella flagellum & 0.83 & 0.28 & 1.14 & 3.20 \\
\hline Bebryce mollis & 0.67 & 0.06 & 1.28 & 2.96 \\
\hline Acanthogorgia armata & 0.61 & 0.17 & 1.08 & 2.88 \\
\hline Lophelia pertusa & 0.17 & 0.56 & 0.92 & 2.87 \\
\hline Callogorgia verticillata & 0.78 & 0.28 & 1.01 & 2.83 \\
\hline Acanthogorgia hirsuta & 0.50 & 0.11 & 1.02 & 2.62 \\
\hline Caryophyllia alberti & 0.56 & 0.11 & 0.73 & 2.60 \\
\hline Villogorgia bebrycoides & 0.56 & 0.11 & 0.93 & 2.57 \\
\hline Schizophytum echinatum & 0.56 & 0.06 & 1.02 & 2.56 \\
\hline Desmophyllum dianthus & 0.39 & 0.39 & 0.69 & 2.50 \\
\hline Shallow vs. Deep & $\begin{array}{l}\text { Av. Abund. } \\
\text { Shallow }\end{array}$ & $\begin{array}{l}\text { Av. Abund. } \\
\text { Deep }\end{array}$ & Diss/SD & $\begin{array}{c}\text { Contrib. } \\
(\%)\end{array}$ \\
\hline Caryophyllia cyathus* & 0.78 & 0.00 & 1.64 & 3.75 \\
\hline Viminella flagellum* & 0.83 & 0.06 & 1.49 & 3.67 \\
\hline Callogorgia verticillata* & 0.78 & 0.00 & 1.44 & 3.54 \\
\hline Acanthogorgia armata & 0.61 & 0.25 & 0.91 & 3.00 \\
\hline Schizophytum echinatum & 0.56 & 0.00 & 1.18 & 2.94 \\
\hline Caryophyllia alberti & 0.56 & 0.00 & 0.71 & 2.65 \\
\hline Bebryce mollis & 0.67 & 0.13 & 1.10 & 2.59 \\
\hline Desmophyllum dianthus & 0.39 & 0.38 & 0.66 & 2.58 \\
\hline Errina dabneyi & 0.50 & 0.06 & 0.91 & 2.57 \\
\hline Villogorgia bebrycoides & 0.56 & 0.00 & 0.97 & 2.46 \\
\hline Acanthogorgia hirsuta & 0.50 & 0.06 & 0.91 & 2.42 \\
\hline Intermediate vs. Deep & $\begin{array}{l}\text { Av. Abund. } \\
\text { Intermediate }\end{array}$ & $\begin{array}{l}\text { Av. Abund. } \\
\text { Deep }\end{array}$ & Diss/SD & $\begin{array}{c}\text { Contrib. } \\
(\%)\end{array}$ \\
\hline Madrepora oculata & 0.61 & 0.50 & 0.65 & 4.65 \\
\hline Lophelia pertusa & 0.56 & 0.31 & 0.83 & 4.28 \\
\hline Desmophyllum dianthus & 0.39 & 0.38 & 0.63 & 3.57 \\
\hline Stephanocyathus moseleyanus & 0.00 & 0.38 & 0.48 & 3.42 \\
\hline Pliobothrus symmetricus & 0.33 & 0.13 & 0.61 & 3.01 \\
\hline Solenosmilia variabilis & 0.28 & 0.31 & 0.67 & 3.01 \\
\hline Candidella imbricata & 0.22 & 0.31 & 0.63 & 2.93 \\
\hline Acanella arbuscula & 0.06 & 0.44 & 0.72 & 2.31 \\
\hline Callogorgia verticillata & 0.28 & 0.00 & 0.57 & 2.21 \\
\hline Chrysogorgia agassizii & 0.11 & 0.13 & 0.48 & 2.19 \\
\hline
\end{tabular}

Acknowledgements. The research leading to these results has received funding from the European Community's Seventh Framework Programme (FP7/2007-2013) under projects CoralFISH (grant agreement no. 213144) and HERMIONE (grant agreement no. 226354), from the Portuguese Foundation for Science and Technology (FCT) under projects CORAZON (FCT/PTDC/MAR/72169/2006) and PEst-OE/EEI/LA0009/2011, from Global Census of Marine Life on Seamounts under the CenSeam minigrant/2008 and also from European Community initiatives under the project BANCOMAC (INTERREG IIIB). For specimen collection deposited in the IMAR-DOP/UAc reference collection, the authors would like to acknowledge (1) captain, crew and scientists of the RV Arquipélago in particular Alexandra Rosa,
Diana Catarino, Clara Loureiro, Gui Menezes, Eva Giacomello, Sérgio Steffanni, Telmo Morato and Octávio Melo, (2) DOP technicians Rui Rosa and Carlos Dias, (3) the longline fishermen's community based at Horta, (4) CoralFISH observers Tiago Bento and Victor Monteiro coordinated by Telmo Morato and (5) project CONDOR (EEA grant - PT0040/2008) and the annual demersal monitoring campaign ARQDAÇO funded by the Azores Government. Leen van Ofwegen of the Naturalis Biodiversity Center Leiden is gratefully acknowledged for allowing the examination of stored specimens from CANCAP-V expedition, and Bastian Reijnen and Sancia van der Meij for their support during the visit (travel of A. Braga-Henriques supported by FP7 - CoralFISH). The cruise with NRP Almirante Gago Coutinho 
and ROV Luso 6000 in 2010 was funded by FP7 - CoralFISH. We also acknowledge Bob Clarke for statistical advice regarding the multivariate analyses and Fernando Tempera for collaborating in the scope of CoralFISH. This work is part of $\mathrm{PhD}$ research of A. Braga-Henriques, funded by a doctoral grant from the Azores Government, through the Regional Fund for Science and Technology (FRCT, ref. M3.1.2/F/016/2008). PAR was supported by an FCT post-doctoral grant (ref. SFRH/BPD/69232/2010). IMAR-DOP/UAc is Research and Development Unit \#531 and LARSyS Associated Laboratory funded by FCT (OE, FEDER, POCI2001, FSE, COMPETE) and by the Azores Directorate for Science, Technology and Communications (DRCTC).

The service charges for this open access publication have been covered by the EC on the scope of FP7 - CoralFISH project (grant agreement no. 213144).

Edited by: R. Danovaro

\section{References}

Alves, M. and Verdière, A. C.: Instability dynamics of subtropical jet and applications to the Azores front systems: eddy-driven mean flow, J. Phys. Oceanogr., 29, 837-863, 1999.

Aurivillius, M.: The gorgonarians from Dr. Sixten Bock's expedition to Japan and Bonin Islands 1914. Kungliga Svenska Vetenskaps-Akademiens Handlingar, Series 3, No. 9, Almqvist \& Wiksells, Stockholm, 1931.

Auster, P. J., Gjerde, K., Heupel, E., Watling, L., Grehan, A., and Rogers, A. D.: Definition and detection of vulnerable marine ecosystems on the high seas: problems with the "move-on" rule, ICES J. Mar. Sci., 68, 254-264, 2011.

Ávila, S. P.: Shallow-water marine molluscs of the Azores: biogeographical relationships, Arquipélago, Life and Marine Sciences, Suppl. 2, 99-130, 2000.

Ávila, S. P. and Malaquias, M. A. E.: Biogeographical relationships of the molluscan fauna of the Ormonde seamount (Gorringe bank, northeast Atlantic Ocean), J. Mollusc. Stud., 69, 145-150, 2003.

Azevedo, J. M. M., Portugal-Ferreira, M. R., and Martins, J. A.: The emergent volcanism of Flores Island, Azores (Portugal), Arquipélago, Life and Earth Sciences, 9, 37-46, 1991.

Baillon, S., Hamel, J.-F., Wareham, V. E., and Mercier A.: Deep cold-water corals as nurseries for fish larvae, Front. Ecol. Environ., 10, 351-356, 2012.

Baker, K. D., Wareham, V. E., Snelgrove, P. V. R., Haedrich, R. L., Fifield, D. A., Edinger, E. N., and Gilkinson, K. D.: Distributional patterns of deep-sea coral assemblages in three submarine canyons off Newfoundland, Canada, Mar. Ecol.-Prog. Ser., 445, 235-249, 2012.

Bashmachnikov, I., Lafon, V., and Martins, A.: Sea surface temperature distribution in the Azores region. Part II: space-time variability and underlying mechanisms, Arquipélago, Life and Marine Sciences, 21A, 19-32, 2004.

Bayer, F. M.: Key to the genera of Octocorallia exclusive of Pennatulacea (Coelenterata, Anthozoa), with diagnosis of new taxa, P. Biol. Soc. Wash., 94, 902-947, 1981.

Bayer, F. M., Grasshoff, M., and Verseveldt, J.: Illustrated trilingual glossary of morphological and anatomical terms applied to Oc- tocorallia, edited by: Brill, E. J. and Backhuys, W., Leiden, 1983. Beazley, L. I. and Kenchington, E. L.: Reproductive biology of the deep-water coral Acanella arbuscula (Phylum Cnidaria: Class Anthozoa: Order Alcyonacea), northwest Atlantic, Deep-Sea Res. Pt. I, 68, 92-104, 2012.

Bergstad, O. A., Menezes, G., and Høines Å. S.: Demersal fish on a mid-ocean ridge: distribution patterns and structuring factors, Deep-Sea Res. Pt. II, 55, 185-202, 2008.

Bergstad, O. A., Menezes, G. M. M., Høines, Å. S., Gordon, J. D. M., and Galbraith, J. K.: Patterns of distribution of deepwater demersal fishes of the North Atlantic mid-ocean ridge, continental slopes, islands and seamounts, Deep-Sea Res. Pt. I, 61, 74-83, 2012.

Billard, A.: Hydroides, in: Expéditions Scientifiques du Travailleur et du Talisman Pendant les Années 1880, 1881, 1883, edited by: Milne-Edwards, A. and Perrier, E., Masson et Cie, Paris, 153243, 1907.

Boschma, H.: On the stylasterine genus Errina, with the description of a new species, P. K. Ned. Akad. C Biol., 66, 391-396, 1963.

Boury-Esnault, N. and Lopes, M. T.: Les démosponges litorales de l'archipel des Açores, Ann. I. Oceanogr. Paris, Nouvelle Séries, 61, 149-225, 1985.

Bower, A. S., Le Cann, L., Rossby, T., Zenk, W., Gould, J., Speer, K., Richardson, P. L., Prater, M. D., and Zhang H.-M.: Directly measured mid-depth circulation in the north Atlantic Ocean, Nature, 419, 603-607, 2002.

Bradbury, I. R., Laurel, B., Snelgrove, P. V. R., Bentzen, P., and Campana, S. E.: Global patterns in marine dispersal estimates: the influence of geography, taxonomic category and life history, P. Roy. Soc. B-Biol. Sci., 275, 1803-1809, 2008.

Braga-Henriques, A., Carreiro-Silva, M., Porteiro, F., Matos, V., Sampaio, Í., Ocaña, O., and Ávila, S. P.: The association between a deep-sea gastropod Pedicularia sicula (Caenogastropoda: Pediculariidae) and its coral host Errina dabneyi (Hydrozoa: Stylasteridae) in the Azores, ICES J. Mar. Sci., 68, 399407, 2011.

Braga-Henriques, A., Carreiro-Silva, M., Tempera, F., Porteiro, F. M., Jakobsen, K., Jakobsen, J., Albuquerque, M., and Santos, R. S.: Carrying behavior in the deep-sea crab Paromola cuvieri (Northeast Atlantic), Mar. Biodiv., 42, 37-46, 2012.

Briggs, J. C.: Marine Zoogeography, McGraw-Hill Book Co., New York, 1974.

Brito, A. and Ocaña, O.: Corales de las Islas Canarias, Francisco Lemos Editor, La Laguna, 2004.

Brooke, S. and Stone, R.: Reproduction of deep-water hydrocorals (family Stylasteridae) from the Aleutian islands, Alaska, B. Mar. Sci., 81, 519-532, 2007.

Bryan, T. L. and Metaxas, A.: Predicting suitable habitat for deepwater gorgonian corals on the Atlantic and Pacific continental margins of north America, Mar. Ecol.-Prog. Ser., 330, 113-126, 2007.

Buhl-Mortensen, L., Vanreusel, A., Gooday, A. J., Levin, L. A., Priede, I. G., Buhl-Mortensen, P., Gheerardyn, H., King, N. J., and Raes, M.: Biological structures as a source of habitat heterogeneity and biodiversity on the deep ocean margins, PSZNI Mar. Ecol., 31, 21-50, 2010.

Cairns, S. D.: A generic revision of the Stylasteridae (Coelenterata: Hydrozoa). Part 3. Keys to the genera, B. Mar. Sci., 49, 538-545, 1991. 
Cairns, S. D.: Deep-water corals: an overview with special reference to diversity and distribution of deep-water scleractinian corals, B. Mar. Sci., 81, 311-322, 2007.

Cairns, S. D. and Chapman, R. E.: Biogeographic affinities of the North Atlantic deep-water Scleractinia, in: Proceedings of the First International Symposium on Deep-sea Corals, edited by: Willison, J. H. M., Hall, J., Gass, S. E., Kenchington, E. L. R., Butler, M., and Doherty, P., Ecology Action Centre, Nova Scotia Museum, Halifax, 30-57, 2001.

Calvet, L.: Bryozoaires provenant des campagnes de l'Hirondelle (1886-1888), Résultats des Campagnes Scientifiques du Prince Albert Ier de Monaco, 23, 1-188, 1903.

Calvet, L.: Diagnoses de quelques espèces nouvelles de bryozoaires cyclostomes provenant des campagnes scientifiques accomplies par S.A.S. le Prince de Monaco, á bord de la Princesse-Alice (1889-1910), Bulletin de l'Institut Océanographique Monaco, 8, $1-9,1911$

Carpine, C. and Grasshoff, M.: Catalogue critique des Octocoralliaires des collections du Musée océanographique de Monaco. I. Gorgonaires et Pennatulaires, Bulletin de l'Institut Océanographique Monaco, 73, 1-72, 1985.

Carreiro-Silva, M., Braga-Henriques, A., Sampaio, I., Matos, V., Porteiro, F., and Ocaña, O.: Isozoanthus primnoidus, a new zoanthid species (Anthozoa: Hexacorallia) associated with the gorgonian Callogorgia verticillata (Anthozoa: Octocorallia) in the Azores, ICES J. Mar. Sci., 68, 408-415, 2011.

Carreiro-Silva, M., Andrews, A. H., Braga-Henriques, A., de Matos V., Porteiro, F. M., and Santos, R. S.: Variability in growth rates of long-lived black coral Leiopathes sp. from the Azores (Northeast Atlantic), Mar. Ecol.-Prog. Ser., 473, 189-199, 2013.

Clarke, K. R. and Gorley, R. N.: PRIMER v6: User Manual/Tutorial, PRIMER-E, Plymouth, 2006.

Clarke, K. R., Somerfield, P. J., and Chapman, M. G.: On resemblance measures for ecological studies, including taxonomic dissimilarities and a zero-adjusted Bray-Curtis coefficient for denuded assemblages, J. Exp. Mar. Biol. Ecol., 330, 55-80, 2006.

CNEXO: Bathyscaphe "Archimède": Campagne 1966 à Madère; Campagne 1969 aux Açores, Publications du Centre National pour l'Exploitation des Océans, 1972.

Collections Search Center, Smithsonian Institution: http://collections.si.edu/search/, last access: 8 March 2012.

Colwell, R. K.: EstimateS: Statistical estimation of species richness and shared species from samples, Version 8, persistent URL ¡purl.oclc.org/estimates $\_, 2006 .$

Colwell, R. K., Mao, C. X., and Chang, J.: Interpolating, extrapolating, and comparing incidence-based species accumulation curves, Ecology, 85, 2717-2727, 2004.

Copley, J. T. P., Tyler, P. A., Sheader, M., Murton, B. J., and German, C. R.: Megafauna from sublittoral to abyssal depths along the Mid-Atlantic Ridge south of Iceland., Oceanol. Acta, 19, 549-559, 1996.

Cordes, E. E., Nybakken, J. W., and VanDykhuizen, G.: Reproduction and growth of Anthomastus ritteri (Octocorallia: Alcyonacea) from Monterey Bay, California, USA, Mar. Biol., 138, 491-501, 2001.

Davies, A. J., Duineveld, G. C. A., Lavaleye, M. S. S., Bergman, M. J. N., Van Haren, H., and Roberts, J. M.: Downwelling and deep-water bottom currents as food supply mechanisms to the cold-water coral Lophelia pertusa (Scleractinia) at the Mingulay
Reef complex, Limnol. Oceanogr., 54, 620-629, 2009.

de Matos, V., Gomes-Pereira, J. N., Tempera, F., Ribeiro, P. A., Braga-Henriques, A., and Porteiro, F.: First record of Antipathella subpinnata (Anthozoa, Antipatharia) in the Azores (NE Atlantic) with description of the first monotypic garden for this species, Deep-sea Res. Pt. II, submitted, 2013.

DLR: Estrutura o Parque Marinho dos Açores: Decreto Legislativo Regional n. ${ }^{\circ}$ 28/2011/A, Diário da República, 1. série - No 217 - 11 November 2011, 4834-4845, 2011.

Dorschel, B., Hebbeln, D., Foubert, A., White, M., and Wheeler, A. J.: Hydrodynamics and cold-water coral facies distribution related to recent sedimentary processes at Galway Mound west of Ireland, Mar. Geol., 244, 184-195, 2007.

EC: Council Regulation (EC) No. 1568/ 2005 of 20 September 2004 amending Regulation (EC) No. 850/98 as regards the protection of deep-water coral reefs from the effect of fishing in certain areas in the Atlantic Ocean, Official Journal of the European Union L252/2, 28 September 2005, 2-3, 2005.

Etter, R. J., Boyle, E. E., Glazier, A., Jennings, R. M., Dutra, E., and Chase, M. R.: Phylogeography of a pan-Atlantic abyssal protobranch bivalve: implications for evolution in the Deep Atlantic, Mol. Ecol., 20, 829-843, 2011.

FAO: International Guidelines for the Management of Deep-sea Fisheries in the High Seas, FAO Fisheries Report No 888, FAO, Rome, 2009.

Frederiksen, R., Jensen, A., and Westerberg, H.: The distribution of the scleractinian coral Lophelia pertusa around the Faroe Islands and the relation to internal tidal mixing, Sarsia, 77, 157$171,1992$.

Galparsoro, I., Connor, D. W., Borja, A., Aish, A., Amorim, P., Bajjouk, T., Chambers, C., Coggan, R., Dirberg, G., Ellwood, H., Evans, D., Goodin, K. L., Grehan, A., Haldin, J., Howell, K., Jenkins, C., Michez, N., Mo, G., Buhl-Mortensen, P., Pearce, B., Populus, J., Salomidi, M., Sánchez, F., Serrano, A., Shumchenia, E., Tempera, F., and Vasquez, M.: Using EUNIS habitat classification for benthic mapping in European seas: Present concerns and future needs, Mar. Pollut. Bull., 64, 2630-2638, 2012.

Gebruk, A. V., Budaeva, N. E., and King, N. J.: Bathyal benthic fauna of the Mid-Atlantic Ridge between the Azores and the Reykjanes Ridge, J. Mar. Biol. Assoc. UK, 90, 1-14, 2010.

Genin, A., Dayton, P. K., and Spiess, F. N.: Corals on seamount peaks provide evidence of current acceleration over deep-sea topography, Nature, 322, 59-61, 1986.

Gotelli, N. J. and Colwell, R. K.: Quantifying diversity: procedures and pitfalls in the measurement and comparison of species richness, Ecol. Lett., 4, 379-391, 2001.

Gourret, P.: Lophohelia prolifera, Amphihelia rostrata, Amphihelia oculata, in: Étude des Coelentérés Atlantiques Recueillies par le Travailleur durant les Campagnes 1880 et 1881, edited by: Marion, A. F., Expéditions Scientifiques du Travailleur et Talisman Pendant les Années 1880, 1881, 1882, 1883, Vayssière, Marseille, France, 103-151, 1906.

Grasshoff, M.: Die Gorgonaria des östlichen Nordatlantik und des Mittelmeeres. II. Die Gattung Acanthogorgia (Cnidaria: Anthozoa). Auswertung der "Atlantischen Kuppenfahrten 1967" von F. S. "Meteor", "Meteor" Forsch.- Ergebnisse Reihe D, 13, 1-10, 1973.

Grasshoff, M.: Die Gorgonarien des östlichen Nordatlantik und des Mittelmeeres. III Die Familie Paramuriceidae (Cnidaria, Antho- 
zoa), "Meteor" Forsch.-Ergebnisse Reihe D, 27, 5-76, 1977.

Grasshoff, M.: Gorgonaria und Pennatularia (Cnidaria: Anthozoa) vom Mittelatlantischen Rücken SW der Azoren, Steenstrupia, 7, 213-230, 1981.

Grasshoff, M.: Die Gorgonaria, Pennatularia, und Antipatharia des Tiefwassers der Biskaya (Cnidaria, Anthozoa). I: Allgemeiner teil, Bulletin du Muséum National d'Histoire Naturelle Paris, 4e Sér., 3 (section A), 731-766, 1982.

Grasshoff, M.: Die Gorgonaria der expeditionen von "Travailleur" 1880-1882 und "Talisman" 1883 (Cnidaria, Anthozoa), Bulletin du Muséum National d'Histoire Naturelle Paris, 4e Sér., 8 (section A), 9-38, 1986.

Grasshoff, M.: Die Flachwasser-Gorgonarien von Europa und Westafrika (Cnidaria, Anthozoa), Cour. Forsch. Senck., 149, 1-135, 1992.

Gravier, C. J.: Note préliminaire sur les Madréporaires recueillis au cours des croisières de la Princesse-Alice et de l'Hirondelle II, de 1893 a 1913 inclusivement, Bulletin de l'Institut Oceanographique Monaco, 12, 1-22, 1915.

Gravier, C. J.: Madréporaires provenant des campagnes des yachts Princesse Alice et Hirondelle II (1893-1913), Résultats des Campagnes Scientifiques du Prince Albert Ier de Monaco, 55, $1-123,1920$.

Gravier, C. J.: Antipathaires provenant des campagnes des yachts Princesse Alice et Hirondelle II (1903-1913), Résultats des Campagnes Scientifiques du Prince Albert Ier de Monaco, 59, 1-29, 1921.

Guinan, J. C., Grehan, A. J., Dolan, M. F. J., and Brown, C.: Quantifying relationships between video observations of cold-water coral and seafloor terrain in Rockall Trough, west of Ireland, Mar. Ecol.-Prog. Ser., 375, 125-138, 2009.

Hall-Spencer, J., Rogers, A. D., Davies, J., and Foggo, A.: Deep-sea coral distribution on seamounts, oceanic islands, and continental slopes in the NE Atlantic, B. Mar. Sci., 81 (Suppl. 1), 135-145, 2007.

Hareide, N. R. and Garnes, G.: The distribution and catch rates of deep water fish along the Mid-Atlantic Ridge from 43 to $61^{\circ} \mathrm{N}$, Fish. Res., 51, 297-310, 2001.

Hickson, S. J.: Notes on some Stylasterina in the Muséum d'Histoire naturelle de Paris, Bulletin du Muséum National d'Histoire Naturelle, Paris, 18, 461-466, 1912.

Howell, K. L., Billett, D. S. M., and Tyler, P. A.: Depth-related distribution and abundance of seastars (Echinodermata: Asteroidea) in the Porcupine Seabight and Porcupine Abyssal Plain, N.E. Atlantic, Deep-Sea Res. Pt. I, 49, 1901-1920, 2002.

Husebø, Å., Nottestad, L., Fosså, J. H., Furevik, D. M., and Jorgensen, S. B.: Distribution and abundance of fish in deep-sea coral habitats, Hydrobiologia, 471, 91-99, 2002.

Johnson, J. and Stevens, I.: A fine resolution model of the eastern North Atlantic between the Azores, the Canary Islands and Gibraltar Strait, Deep-Sea Res. Pt. I, 47, 875-899, 2002.

Jourdan, E.: Zoanthaires provenant des campagnes du yacht l'Hirondelle (Golfe de Gascogne, Açores, Terre-Neuve), Résultats des Campagnes Scientifiques du Prince Albert Ier de Monaco, 8, 1-36, 1895.

Koslow, J. A., Gowlett-Holmes, K., Lowry, J. K., O’Hara, T., Poore, G. C. B., and Williams, A.: Seamount benthic macrofauna off Tasmania: community structure and impacts of trawling, Mar. Ecol.-Prog. Ser., 213, 111-125, 2001.
Lester, S. E., Ruttenberg, B. I, Gaines, S. D., and Kinlan, B. P.: The relationship between dispersal ability and geographic range size, Ecol. Lett., 10, 745-758, 2007.

Lindström, G.: Contribution to the Actinology of the Atlantic Ocean, Kungliga Svenska Vetenskaps-akademiens Handlingar, 14, 1-26, 1877.

Lopes, M. F. R., Marques, J. C., and Bellan-Santini, D.: The benthic amphipod fauna of the Azores (Portugal): an up-to-date annotated list of species, and some biogeographic considerations, Crustaceana, 65, 204-217, 1993.

López-González, P. J. and Gili, J. M.: A new genus and species of stoloniferous octocoral from Azores Archipelago (Cnidaria, Anthozoa), Bulletin of the Biological Society of Washington, 10, 130-139, 2001.

Lourenço, N., Miranda, J. M., Luis, J. F., Ribeiro, A., Mendes Victor, L. A., Madeira, J. and Needham, H. D.: Morpho-tectonic analysis of the Azores volcanic plateau from a new bathymetric compilation of the area, Mar. Geophys. Res., 20, 141-156, 1998.

Malaquias, M. A. E., Calado, G. P., Padula, V., Villani, G., and Cervera, J. L.: Molluscan diversity in the North Atlantic Ocean: new records of opisthobranch gastropods from the Archipelago of the Azores, Marine Biodiversity Records, e38, 1-9, 2009.

McClain, C. R. and Hardy, S. M.: The dynamics of biogeographic ranges in the deep sea, P. Roy. Soc. B-Biol. Sci., 277, 3533-3546, 2010.

McClain, C. R., Lundsten, L., Ream, M., Barry, J., and DeVogelaere, A.: Endemicity, biogeography, composition, and community structure on a northeast Pacific Seamount, PLoS ONE, 4, e4141, doi:10.1371/journal.pone.0004141, 2009a.

McClain, C. R., Rex, M. A., and Etter, R. J.: Patterns in deep-sea macroecology, in: Marine Macroecology, edited by: Witman, J D. and Roy, K., Chapter 3, University of Chicago Press, Chicago, 2009b.

McFadden, C. S., Benayahu, Y., Pante E., Thoma, J. N., Nevarez, P. A., and France, S. C.: Limitations of mitochondrial gene barcoding in Octocorallia, Mol. Ecol. Resour., 11, 19-31, 2011.

Menezes, G. M.: Demersal fish assemblages in the Atlantic Archipelagos of the Azores, Madeira, and Cape Verde, PhD thesis, Universidade dos Açores, Horta, 2003.

Menezes, G. M., Sigler, M. F., Silva, H. M., and Pinho, M. R.: Structure and zonation of demersal fish assemblages off the Azores archipelago (Mid Atlantic), Mar. Ecol.-Prog. Ser., 324, 241-260, 2006.

Mercier, A. and Hamel, J.-F.: Contrasting reproductive strategies in three deep-sea octocorals from eastern Canada: Primnoa resedaeformis, Keratoisis ornata, and Anthomastus grandiflorus, Coral Reefs, 30, 337-350, 2011.

Mienis, F., de Stigter, H. C., White, M., Duineveld, G., de Haas, H., and van Weering, T. C. E.: Hydrodynamic controls on cold-water coral growth and carbonate-mound development at the SW and SE Rockall Trough Margin, NE Atlantic Ocean, Deep-Sea Res. Pt. I, 54, 1655-1674, 2007.

Miller, K. J., Rowden, A. A., Williams, A., and Häussermann, V.: Out of their depth? Isolated deep populations of the cosmopolitan coral Desmophyllum dianthus may be highly vulnerable to environmental change, PLoS ONE, 6, doi:10.1371/journal.pone.0019004, e19004, 2011. 
Molodtsova, T. N.: Black corals (Antipatharia: Anthozoa: Cnidaria) of the north-eastern Atlantic, in: Biogeography of the Atlantic Seamounts, edited by: Mironov, A. N., Gebruk, A. V., and Southward, A. J., KMK Scientific Press, Moscow, 141-151, 2006.

Molodtsova, T. N., Sanamyan, N. P., and Keller, N. B.: Anthozoa from the northern Mid-Atlantic Ridge and Charlie-Gibbs Fracture Zone, Mar. Biol. Res., 55, 112-130, 2008.

Morato, T., Machete, M., Kitchingman, A., Tempera, F., Lai, S., Menezes, G., Pitcher, T. J., and Santos, R. S.: Abundance and distribution of seamounts in the Azores, Mar. Ecol.-Prog. Ser., 357, 23-32, 2008.

Morato, T., Pitcher, T. J., Clark, M. R., Menezes, G., Tempera, F., Porteiro, F., Giacomello, E., and Santos, R.S.: Can we protect seamounts for research? A call for conservation, Oceanography, 23, 190-199, 2010.

Mortensen, P. B. and Buhl-Mortensen, L.: Distribution of deepwater gorgonian corals in relation to benthic habitat features in the Northeast Channel (Atlantic Canada), Mar. Biol., 144, 12231238,2004

Mortensen, P. B., Buhl-Mortensen, L., Gebruk, A. V., and Krylova, E. M.: Occurrence of deep-water corals on the Mid-Atlantic Ridge based on MAR-ECO data, Deep-Sea Res. Pt. II, 55, 142152,2008

Moseley, H. N.: Report on certain hydroid, alcyonarian, and madreporarian corals procured during the voyage of H.M.S. Challenger, in the years 1873-1876, Report on the Scientific Results of the Voyage of H.M.S. Challenger during the years 187376, Zoology, 2, 1-248, 1881.

Moss, D. S.: A summary of the Porifera collected during "Expedition Azores 1989", Arquipélago, Life and Earth Sciences, 10, 45-53, 1992.

Ocaña, O., López-González, P. J., Núñez, J., and García-Gómez, J. C.: A survey of the genera Sarcodictyon Forbes, 1847, and Rolandia Lacaze-Duthiers, 1900, (Anthozoa: Octocorallia) in the North-eastern Atlantic and the Mediterranean, Zool. Med. Leiden, 73, 413-426, 2000.

Ocaña, O., Henriques, A., and Porteiro, F.: An occurrence of ring sea anemones (Anthozoa, Actiniaria) in the Azores region, Graellsia, 63, 359-362, 2007.

O’Connor, M. I., Bruno, J. F., Gaines, S. D., Halpern, B. S., Lester, S. E., Kinlan, B. P., and Weiss, J. M.: Temperature control of larval dispersal and the implications for marine ecology, evolution, and conservation, P. Natl. Acad. Sci. USA, 104, 1266-1271, 2007.

O'Hara, T. D.: Seamounts: centres of endemism or species richness for ophiuroids, Global Ecol. Biogeogr., 16, 720-732, 2007.

Opresko, D. M.: Revision of the Antipatharia (Cnidaria: Anthozoa). Part V. Establishment of a new family, Stylopathidae, Zool. Med. Leiden, 80-4, 109-138, 2006.

OSPAR: Background document for coral gardens, Biodiversity Series, Publication Number: 486/2010, 2010.

Pax, F. and Müller, I.: Catalogue des types d'Anthozoaires du Musée océanographique de Monaco, Bulletin de l'Institut Océanographique Monaco, 51, 1-40, 1954.

Pourtalès, L. F.: Deep-sea corals, Illustrated Catalogue of the Museum of Comparative Zoölogy, 4, 1-93, 1871.

Probert, P. K., Christiansen, S., Gjerde, K. M., Gubbay, S., and Santos, R. S.: Management and conservation of seamounts, in: Seamounts: Ecology Fisheries and Conservation, edited by:
Pitcher, T. J., Morato, T., Hart, P. J. B., Clark, M. R., Haggan, N., and Santos, R. S., Blackwell Fisheries and Aquatic Resources Series 12, Blackwell Publishing, Oxford, 442-475, 2007.

R Development Core Team: R: A language and environment for statistical computing, R Foundation for Statistical Computing, 2011.

Reveillaud, J., Freiwald, A., van Rooij, D., Le Guilloux, E., Altuna, A., Foubert, A., Vanreusel, A., Olu-Le Roy, K., and Henriet, J.P.: The distribution of scleractinian corals in the Bay of Biscay, NE Atlantic, Facies, 54, 317-331, 2008.

Reverdin, G., Niiler, P. P., and H. Valdimarsson, H.: North Atlantic Ocean surface currents, J. Geophys. Res., 108, 3002-3023, 2003.

Richer de Forges, B., Koslow, J. A., and Poore, G. C. B.: Diversity and endemism of the benthic seamount fauna in the south-west Pacific, Nature, 405, 944-47, 2000.

Roark, E. B., Guilderson, T. P., Dunbar, R. B., Fallon, S. J., and Mucciarone, D. A.: Extreme longevity in proteinaceous deep-sea corals, P. Natl. Acad. Sci. USA, 106, 5204-5208, 2009.

Roberts, J., Wheeler, A., and Freiwald, A.: Reefs of the deep: the biology and geology of cold-water coral ecosystems, Science, 312, 543-547, 2006.

Roule, L.: Notice préliminaire sur les Antipathaires provenant des collections du Prince du Monaco, Mémoires de la Société Zoologique de France, 15, 228-239, 1902.

Roule, L.: Description des Antipathaires et Cérianthaires recueillis par S.A.S. le Prince de Monaco dans l'Atlantique Nord (18861902), Résultats des campagnes scientifiques du Prince Albert Ier de Monaco, 30, 1-99, 1905.

Rowden, A. A., Schnabel, K. E., Schlacher, T. A., Macpherson, E., and Ahyong, S. T.: Squat lobster assemblages on seamounts differ from some, but not all, deep-sea habitats of comparable depth, PSZNI Mar. Ecol., 31 (Suppl. S1), 63-83, 2010.

Samadi, S., Bottan, L., Macpherson, E., Richer de Forges, B., and Boisselier M.-C.: Seamount endemism questioned by the geographic distribution and population genetic structure of marine invertebrates, Mar. Biol., 149, 1463-1475, 2006.

Sampaio, I., Ocaña, O., Tempera, F., Braga-Henriques, A., Matos, V., and Porteiro, F.: New occurrences of Corallium spp. (Octocorallia, Coralliidae) in the Central Northeast Atlantic, Arquipélago, Life and Marine Sciences, 26, 73-78, 2009.

Sampaio, I., Braga-Henriques, A., Pham, C., Ocaña, O., de Matos, V., Morato, T., and Porteiro, F.: Cold-water corals landed by bottom longline fishery in the Azores, J. Mar. Biol. Assoc. UK, 92, 1547-1555, 2012.

Santos, R. S, Hawkins, S., Monteiro, L. R., Alves, M., and Isidro, E. J.: Marine research, resources and conservation in the Azores, Aquat. Conserv., 5, 311-354, 1995.

Shanks, A. L.: Pelagic larval duration and dispersal distance revisited, Biol. Bull., 216, 373-385, 2009.

Sherwood, O. A. and Edinger, E. N.: Ages and growth rates of some deep-sea gorgonian and antipatharian corals of Newfoundland and Labrador, Can. J. Fish. Aquat. Sci., 66, 142-152, 2009.

Söffker, M., Sloman, K. A., and Hall-Spencer, J.: In situ observations of fish associated with coral reefs off Ireland, Deep Sea Res. Pt. I, 58, 818-825, 2011.

Somero, G. N.: Adaptation to cold and depth: contrasts between polar and deep-sea animals, in: Cold Ocean Physiology, edited by: Pörtner, H. O. and Playle, R. C., University Press, Cambridge, UK, 33-57, 1998. 
Stocks, K. and Hart, P. J. B.: Biogeography and biodiversity of seamounts, in: Seamounts: Ecology Fisheries and Conservation, edited by: Pitcher, T. J., Morato, T., Hart, P. J. B., Clark, M. R., Haggan, N., and Santos, R. S., Blackwell Fisheries and Aquatic Resources Series 12, Blackwell Publishing, Oxford, 255-281, 2007.

Stokvis, F. R. and van Ofwegen, L. P.: New and redescribed encrusting species of Alcyonium from the Atlantic Ocean (Octocorallia: Alcyonacea: Alcyoniidae), Zool. Med. Leiden, 80-4, 165-183, 2006.

Studer, T.: Supplementary report on the Alcyonaria collected by H.M.S. Challenger during the years 1873-76, The Voyage of H.M.S. Challenger, Zoology, 81, 1-31, 1889.

Studer, T.: Note préliminaire sur les Alcyonaires provenant des campagnes du yacht L'Hirondelle 1886, 1887, 1888, Mémoires de la Société Zoologique de France, 3, 551-559, 1890.

Studer, T.: Note préliminaire sur les Alcyonaires provenant des campagnes du yacht L'Hirondelle 1886, 1887, 1888. Seconde Partie. Alcyonacea and Pennatulacea, Mémoires de la Société Zoologique de France, 4, 86-95, 1891.

Studer, T.: Alcyonaires provenant des campagnes de l'Hirondelle (1886-88), Résultats des Campagnes Scientifiques du Prince Albert Ier de Monaco, 20, 1-64, 1901.

Sun, Z., Hamel, J.-F., Edinger, E., and Mercier, A.: Planulation periodicity, settlement preferences and growth of two deep-sea octocorals from the northwest Atlantic, Mar. Ecol.-Prog. Ser., 410, 71-87, 2010.

Surugiu, V., Dauvin J.-C., Gillet, P., and Ruellet, T.: Can seamounts provide a good habitat for polychaete annelids? Example of the northeastern Atlantic seamounts, Deep-Sea Res. Pt. I, 55, 15151531, 2008.

Sutton, T. T., Porteiro, F. M., Heino, M., Byrkjedal, I., Langhelle, G., Anderson, C. I. H., Horne, J., Søiland, H., Falkenhaug, T., Godø, O. R., and Bergstad, O. A.: Vertical structure, biomass and topographic association of deep-pelagic fishes in relation to a mid-ocean ridge system. Deep-Sea Res. Pt. II, 55, 161-184, 2008.

Tempera, F., Giacomello, E., Mitchell, N., Campos, A. S., BragaHenriques, A., Martins, A., Bashmachnikov, I., Morato, T., Colaço, A., Porteiro F. M., Catarino, D., Gonçalves, J., Pinho, M. R., Isidro, E. J., Santos, R. S., and Menezes, G.: Mapping the Condor seamount seafloor environment and associated biological assemblages (Azores, NE Atlantic), in: Seafloor Geomorphology as Benthic Habitat: Geohab Atlas of Seafloor Geomorphic Features and Benthic Habitats, edited by: Baker, E. and Harris, P., Elsevier Insights, 807-818, 2012.

Thoma, J. N., Pante, E., Brugler, M. R., and France, S. C.: Deepsea octocorals and antipatharians show no evidence of seamountscale endemism in the NW Atlantic, Mar. Ecol.-Prog. Ser., 397, 25-35, 2009.

Thomson, J. A.: Alcyonaires provenant des campagnes scientifiques du prince Albert Ier de Monaco, Résultats des Campagnes Scientifiques du Prince Albert Ier de Monaco, 73, 1-77, 1927.

Tixier-Durivault, A. and d'Hondt, M.-J.: Les octocoralliaires de la campagne Biaçores, Bulletin du Muséum National d'Histoire Naturelle, Paris (Série 3) n²52, Zoologie, 174, 1361-1433, 1975.

Tong, R., Purser, A., Unnithan, V., and Guinan, J.: Multivariate statistical analysis of distribution of deep-water gorgonian corals in relation to seabed topography on the Norwegian margin, PLoS ONE, 7, e43534, doi:10.1371/journal.pone.0043534, 2012.

van der Land, J.: Report on the CANCAP-project for marine biological research in the Canarian - Cape Verdean region of the North Atlantic Ocean (1976-1986). Part I. List of Stations, CANCAPproject, Contributions no.74, Zoologische Verhandelingen, 243, 1-94, 1987.

Verrill, A. E.: List of the polyps and coral sent by the Museum of Comparative Zoölogy to other institutions in exchange, with annotations, Bulletin of the Museum of Comparative Zoölogy, 1, 29-60, 1864.

Verrill, A. E.: Report of the Canadian Arctic Expedition 1913-18. VIII: Mollusks, Echinoderms, Coelenterates, Etc. Part G: Alcyonaria and Actiniaria, Ottawa, 1922.

Wagner, D., Waller, R. G., Montgomery, A. D., Kelley, C. D., and Toonen, R. J.: Sexual reproduction of the Hawaiian black coral Antipathes griggi (Cnidaria: Antipatharia), Coral Reefs, 31, 795-806, 2012.

Waller, R. G.: Deep-water Scleractinia (Cnidaria: Anthozoa): current knowledge of reproductive processes, in: Cold-water Corals and Ecosystems, edited by: Freiwald, A. and Roberts, J. M., Springer-Verlag, Berlin Heidelberg, 691-700, 2005.

Wareham, V. E. and Edinger, E. N.: Distribution of deep-sea corals in the Newfoundland and Labrador region, Northwest Atlantic Ocean, B. Mar. Sci., 81 (Suppl. 1), 289-313, 2007.

Watling, L., France, S. C., Pante, E., and Simpson, A.: Biology of deep-water octocorals, in: Advances in Marine Biology, edited by: Lesser, M., Academic Press, 41-122, 2011.

Weinberg, S.: A redescription of the specimens of "Telesto humilis" (Octocorallia) collected by Prince Albert Ier of Monaco, with the description of four new species, Beaufortia, 41, 205-218, 1990.

Wilson Jr., R. R., and Kaufman, R. S.: Seamount biota and biogeography, in: Seamounts, Islands, and Atolls, edited by: Keating, B. H., Fryer, P., Batiza, R., and Boehlert, G.W., American Geophysical Union, Washington DC, 355-377, 1987.

Wright, E. P. and Studer, T.: Report on the Alcyonaria collected by H.M.S. Challenger during the years 1873-76, Report on the Scientific Results of the Voyage of H.M.S. Challenger during the years 1873-76, Zoology, 31, $314+72$ pp., 1889.

Yeh, J. and Drazen, J. C.: Depth zonation and bathymetric trends of deep-sea megafaunal scavengers of the Hawaiian Islands, DeepSea Res. Pt. I, 56, 251-266, 2009.

Zardus, J. D., Etter, R. J., Chase, M. R., Rex, M. A., and Boyle, E. E.: Bathymetric and geographic population structure in the pan-Atlantic deep-sea bivalve Deminucula atacellana (Schenck, 1939), Mol. Ecol., 15, 639-651, 2006.

Zibrowius, H.: Les scléractiniaires de la Méditerranée et de l'Atlantique nord-oriental, Mémoires de l' Institut Oceanographique, 11, 1-227 (planches, text, annexes), 1980.

Zibrowius, H. and Cairns, S. D.: Revision of the northeast Atlantic and Mediterranean Stylasteridae (Cnidaria: Hydrozoa), Memoir. Mus. Natl. Hist. (Serie A, Zoologie), 153, 1-136, 1992.

Zibrowius, H. and Saldanha, L.: Scléractiniaires récoltes en plongée au Portugal et dans les archipels de Madère et des Azores, Bol. Soc. Port. Cienc. Nat., 16, 91-114, 1976. 